\title{
POLITIČNOGEOGRAFSKA ANALIZA BALKANA
}

\author{
dr. Jernej Zupančič \\ Oddelek za geografijo, Filozofska fakulteta Univerze v Ljubljani \\ Aškerčeva 2, SI- I000 Ljubljana \\ e-mail: jernej.zupancic@guest.arnes.si
}

Izvirni znanstveni članek

COBISS 1.01

\section{Izvleček}

Prispevek analizira sodobni politični zemljevid Balkana s pomočjo morfološke, strukturne in funkcijske analize. Za to območje so značilne pogoste spremembe političnih meja, države so mlade, večinoma majhne, etnično mešane in $\mathrm{z}$ obsežnimi perifernimi območji. Večina narodov ima dve politično-teritorialni enoti. Te države so vse po vrsti ranljive, zato je tudi latentni krizni potencial visok. Opisane razmere ustvarjajo specifične periferne pokrajine. $\mathrm{Na}$ drugi strani se močno povečuje tranzitna prometno-strateška funkcija Balkanskega polotoka.

Ključne besede: politična geografija, geopolitika, Balkan, Jugovzhodna Evropa, narodno vprašanje

\section{POLITICAL-GEOGRAPHICAL ANALYSIS OF THE BALKANS}

\begin{abstract}
The paper deals with contemporary political map of the Balkans, founded on morphological, structural and functional analysis. Characteristically, there are frequent changes of political borders in common. The most of nation-states are relatively young, small-sized, ethnic heterogeneous. The space is characteristic by large peripheral areas, but the core areas are small. The most of nations have two spatial-political units. All these nation-states are weak and vulnerable, and that is why they represent a high latent crisis potential. On the other hand, the transport, transit and strategic role of this area is increasing, indeed.
\end{abstract}

Key words: political geography, geopolitics, Balkans, Southeastern Europe, ethnic question 


\section{UVOD}

Ozemlje med Jadranskim, Jonskim, Egejskim, Marmarskim in Črnim morjem - kar okvirno označuje morsko zamejitev Balkanskega polotoka - je nedvomno med geopolitično najbolj dinamičnimi območji evropske celine. Po skoraj polstoletnem zatišju hladne vojne, ki je državam tega območja z različno, a skoraj povsod navzočo totalitarno ureditvijo prinesla krepke družbene in prostorske spremembe, je sledilo burnih dvajset let državnopolitičnih rekonstrukcij. Medtem ko je srednja in zahodna Evropa v zagonu oblikovala ohlapno zvezo evropskih držav - Evropsko unijo, je tu sledila faza razdruževanja in nastajanja novih držav. Čeprav je ta proces prav zaradi vloge nacionalnih držav v Evropski uniji logičen, pogosto ni bil razumljen in so ga radi opredeljevali kot novo fazo 'balkanizacije' - politično-teritorialnega drobljenja. Obdobje tranzicije je pometlo ne le s socializmom kot družbeno-gospodarskim redom, temveč tudi korenito spremenilo politični zemljevid Jugovzhodne Evrope, ki je zopet postajal Balkan. A s tem nikakor ne pristajamo na pejorativno rabo tega izraza; Balkan je nesporno zgodovinsko in tudi geografsko utemeljen. Ne nazadnje je s pojmom Zahodnega Balkana dobil svoj operativni pomen: označuje ozemlje držav, ki še čakajo na vključitev med članice Evropske unije.

Po dveh desetletjih tranzicije in burnih medetničnih odnosov, ki so se neredko razširili $\mathrm{v}$ odprte konflikte, se zdi, da je zavladalo zatišje. Bojišča na tleh nekdanje Jugoslavije so utihnila in obsežni programi nadzora in pomoči naj bi območja (kot sta zlasti Bosna in Hercegovina ter Kosovo) usmerila v evropske gospodarske, družbene in politične vode. Toda spričo mnogih latentnih napetosti, ki jih predstavljajo očitno neuresničeni nacionalizmi malih narodov, se smemo upravičeno vprašati, ali smo res že pri koncu dinamičnega državotvorja in ustvarjanja novega, niti ne najbolj preglednega političnega zemljevida. Prav tako očitno je tudi, da evropske sile ne premorejo koncepta ureditve odnosov na Balkanu. Rekonstrukcija držav je potekala burno, naslonjena na silno moč nacionalizmov in etatizmov, ki so si skušali na različne načine in pogosto s silo utreti pot med evropske zvezde. Vendar se je uresničitev ideala 'etnično homogenih' teritorijev (tudi tokrat) izjalovila. Z napovedmi o 'končni' vključitvi držav Jugovzhodne Evrope v Evropsko unijo in pričakovanjem, da bo to botrovalo koncu medetničnih spopadov, EU le razgalja svojo nemoč, ustvarjeno na iluziji evropskega dogovorništva in pravokracije. Podrobnejša analiza politično-teritorialnih sprememb na prostoru, ki je nekoč uradno nosil ime 'Jugovzhodna Evropa' ter se izogibal pejorativnega 'Balkana', kaže, da smo se iz komaj preteklih sporov, spopadov in medetničnih konfliktov naučili bore malo. Balkanski polotok je tako ostal prizorišče mednarodnega zanimanja, ohranil je mnoge prvine latentnega kriznega območja in predvsem zelo obsežne in globoke družbene in prostorske spremembe, tako značilne za postkrizne situacije in območja. Današnji politični zemljevid Balkana tvorijo etnično precej heterogene države, zajete v podedovane teritorialne okvire. Obilica notranjih in tudi zunanjih napetosti le opozarja na labilno ravnovesje, ustvarjeno z močno asistenco zunanjih sil in zadrževanjem političnega, vojaškega in še posebej gospodarskega nadzora. Balkan tako ostaja območje geopolitičnih eksperimentov in svojevrsten test resnosti geopolitike EU, ki mora stabilnost pred domačim pragom najprej ustvariti in nato tudi vzdrževati.

Čeprav je bilo o Balkanu napisanih že veliko del, ostaja ta del Evrope priljubljen cilj analiz raznim znanstvenim panogam. Ne pozabimo, da so 'balkanske študije' uvedli na kar 
nekaj univerzah, hoteč si pri tem zagotoviti svoj kos znanstvene pogače, posredno pa tudi uveljavljati svoj vpliv. Gotovo ni naključje, da so bile pri tem tradicionalno močne institucije v Nemčiji, Avstriji, Italiji, Veliki Britaniji in Franciji, pa tudi v ZDA. Te države so imele vseskozi prisotno 'balkansko' politiko; tisto torej, ki se je podrobneje posvečala značilnostim tega območja, njegovi kulturi, politiki, gospodarstvu in odprtim družbenim vprašanjem.

Morda je presenetljivo, da evropska diplomacija kljub številnim obsežnim analizam v odločilnih trenutkih ni zmogla kolikor toliko enovite politike do Balkana in predvsem ne predvideti in ne razrešiti domnevnih gordijskih vozlov spontane etnopolitike narodov in držav, ki so tik pred združevalno fazo Evrope planili v spopad za ozemlje in prepir za etnične definicijel Čeprav je po intervencijah sledila faza prisilnega miru, pa strukturna in morfološka analiza teh držav kaže na nedokončanost procesa tvorbe nacionalnih držav in torej na sorazmerno velik konfliktni potencial tega območja.

Namen prispevka je kritična morfološka in strukturna analiza političnega zemljevida Balkana - Jugovzhodne Evrope, pregled novejših politično-teritorialnih sprememb in interpretacija sodobnih medetničnih razmerij, bodisi notranjih (znotrajdržavnih) in zunanjih (meddržavnih). Postavimo tezo, da so nacionalizmi v tem prostoru odločilno vplivali na oblikovanje držav in odnosov med njimi. Prav podcenjevanje latentne energije nacionalizmov je botrovalo (in žal še vedno) mnogim zablodam na diplomatsko-političnem polju 'balkanskih' politik EU. Druga teza pa poudarja parcialni pristop držav zaščitnic posameznih interesov, ki so v zgodovini izigravale številna notranja nasprotja. Tako se je skozi nekaj stoletij odvijala periferizacija Balkanskega polotoka, evropska geopolitika do tega prostora pa je vse bolj postajala geošahistika: ključni igralci so bili zunaj polj spopada, a vendar so bistveno prispevali k moduliranju politično-teritorialnih enot. Domače sile so vseskozi težile k realizaciji enakih nacionalnih ciljev kot drugje v Evropi: tvorbi homogenih nacionalnih držav na eni ter zaokroženju pripadnikov enega naroda $\mathrm{v}$ okviru ene politične enote.

\section{TEORETIČNA PERSPEKTIVA IN METODOLOŠKE OPOMBE}

Iz uvodnega zapisa izhaja, da so bile geografske analize Balkana v javnih in tudi političnih polemikah premalo prisotne. Morda je krivda tudi v naravnanosti geografije, ki je bila morda premalo odzivna, ali pa se je zatekala k preveč preprostim opisnim podajanjem in analizi, preskromno pa je skušala izpostaviti tudi političnogeografske dimenzije in vzročnoposledične odnose. Zato v balkanskih študijah ne manjka sklicevanje na 'pretirano' moč zgodovinskih usod in vplivnost zgodovinske dediščine na eni ter usodnost vsakokratnih politik na drugi strani, vključno z upoštevanjem nacionalnih gibanj kot ključnega gibala pri tvorbi in preoblikovanju držav na vsem starem kontinentu.

V moderni politični geografiji je obravnavi države in družb odmerjene veliko pozornosti; saj gre navsezadnje za enega ključnih predmetov tako klasičnega kakor modernega političnogeografskega razmišljanja. Za te potrebe se je že skoraj pred stoletjem razvila analiza držav, ki je upoštevala predvsem fizične elemente: velikost, obliko državnega ozemlja in

1 Primer Makedoncev in Bošnjakov, ki so jih sosedje (in jih nekateri še sedaj) videli kot del ‘svojega’ naroda oz. skupnosti. 
lastnosti ozemlja. Ta klasični pristop danes ne zadošča več, čeprav ni nepomemben. V ospredje sedaj postavljamo strukturno in funkcijsko analizo. Danes je premislek o državi še toliko bolj utemeljen in potreben, ker evropske države s prehajanjem v Evropsko unijo pomembno spreminjajo tudi naravo, strukturo, vpliv in pomen nacionalne države, kakršne so se razvile v obdobju moderne evropske zgodovine od 18. st. dalje. Toda že tedaj so imele države zelo različno 'dediščino', torej zgodovinske okoliščine, v katerih so utemeljevale svoj obstoj in razvoj. Toda tu že pridemo do dveh, po svoji naravi nasprotujočih si pravic: pravice države do obstoja in pravice narodov do samoodločbe. Prva se veže na politično omejeno in organizirano ozemlje, ki je ob ustrezni strukturi oblasti postalo država. Praviloma se zanjo zavzemajo vse starejše države, ki temeljijo na dediščini fevdalnih državnopolitičnih enot, npr. Francija, Velika Britanija, Španija ali Švedska. Ko so se tudi na teh območjih javljala gibanja za avtonomijo ali celo osamosvojitev (in se še vedno; npr. v Španiji), posluha za ta gibanja seveda ni bilo. Očitno so bile združevalne sile glavne (titularne) narodne (etnične; jezikovne) skupine dovolj močne, da so uspele tudi praktično (s silo) zadrževati teritorialni okvir (Tunjić 2004, 58-59; po Brown 1993). Tega 'zgodovinskega' prava (pravice) o ozemeljski nedotakljivosti (in torej nedeljivosti) pa so se kasneje pričele posluževati tudi države, ki so jih ustvarila dovolj organizirana gibanja - dejansko torej nacionalizmi-številčnih narodov zlasti Srednje, Vzhodne in Jugovzhodne Evrope. Tu je veljalo 'etnično' načelo, v okviru katerega so stremeli k oblikovanju enotne države na vseh tistih ozemljih, za katera so smatrali, da na njih prebivajo pripadniki istega naroda. Omenjeno načelo se je izkazalo za precej sporno, saj so bila obsežna območja naseljena s pripadniki več narodov in jezikovnih ter verskih skupin, kar je zaostrilo odnose med njimi in v posameznih fazah vodilo k spopadu za ozemlje.

Zanimiv primer tega so Nemci, ki so zaradi vpliva še izza srednjeveških državnih tvorb ter selitev zaradi trgovine in različnih služb kapilarno naseljevali obsežna območja Srednje in Vzhodne Evrope. Nemške agresivne ideologije, vključno s klasično nemško geopolitiko, npr. K. Haushoferja, so v teh razpršenih jedrih videle element 'nemške kulture' in jih skušale osvojiti. Seveda so bila ta ozemlja Nemčiji dejansko 'potrebna', ne glede na etnični in kulturni značaj njihovih prebivalcev (Tunjić 2004, 320). Seveda, to je bil potrebni 'življenjski prostor' (nem. Lebensraum) in torej razlog, ali pa vsaj alibi, za poskuse politično-teritorialnih sprememb. Vendar bi naredili grobo napako, če bi tovrstno ideologijo pripisali zgolj Nemčiji. $\mathrm{Ne}$, bila je lastna domala vsem. Razlike so bile predvsem v načinih in pa v operativni moči, kako izpeljati te 'nacionalne' cilje.

Povsem drugačne so bile razmere na Balkanskem polotoku, ki je od srede 19. st. dalje tonil v evropsko socialnogospodarsko periferijo, obenem pa naglo in močno spreminjal politični in etnični zemljevid. 'Balkanizacija', kot so (nedvomno rahlo zaničljivo) poimenovali ta proces državotvorja na Balkanskem polotoku, je hitro postal obči pojem in kakor kaže, še dolgo ne bo zatonil v pozabo. Toda pridobljene 'pravice' (beri: ozemlja) teh 'etničnih' držav (ki so torej nastale $\mathrm{z}$ uresničevanjem pravice do samoodločbe) so le-te branile (in jih še vedno) prav s sklicevanjem na pravico do nedeljivosti državnega ozemlja, tudi če je kulturna oziroma narodna podoba očitno drugačna.

Značilen primer je prav Srbija, nastala s postopnim osamosvajanjem etnično 'srbskih' ozemelj. Toda že Garašaninove 'Načertanije' iz srede 19. st. so dober primer nacionalne geopolitike, ki primarnemu cilju (rasti države in zagotovitvi zadostnih strateških virov za njen 
obstoj in razvoj) podreja vse ostalo. To obdobje je pač bilo stoletje trušča nacionalističnih zahtev povsod po Evropi. Toda po stoletju in pol se je morala soočiti z močjo albanskega nacionalizma ter zaradi mednarodnega konteksta in razmerja moči soočiti z odcepljanjem dela državnega ozemlja, čeprav je bila nanj mitološko in zgodovinsko izjemno močno navezana. Prav osamosvajanje Kosova je bil očitno pretrd preizkusni kamen za enotno evropsko (EU) stališče do pojava nove nacionalne države. Podrobnosti okrog definicij Kosova kot države lahko - ob vsej kritičnosti - pustimo za kako drugo priložnost. Podobno ravna Grčija v odnosu do Makedonije, ko ji brani uradno uporabo imena Makedonija, sklicujoč se na zgodovinsko pravo, izvirajoče še izpred dveh tisočletij. Le malo drugačen je kontekst odnosov Bolgarije do Makedonije, saj Makedoncem odreka nacionalno bit in s tem obstoj; zanje so pač (le!) Bolgari. Zelo sorodne zadrege so se javljale v srbsko-hrvaškem dokazovanju glede prebivalstva Bosne in Hercegovine.

Ta kratek ekskurz v razpravo o narodu in državi je potreben, da predočimo nujo po analizi sodobnega političnega zemljevida Balkanskega polotoka. V nadaljevanju bomo za to uporabili morfološko, strukturno in funkcijsko analizo držav. Pri tem bomo prvenstveno opazovali naslednje elemente: velikost in obliko državnega ozemlja, razmerja med središčem in periferijo, maritimnost (namorskost), glavne poteze narodne (etnične) sestave prebivalstva in značilnosti politično-teritorialne organiziranosti. Temu sledi še funkcijska analiza, kjer so posebej izpostavljene realne in potencialne funkcije različnih ozemelj. V celoti torej prevladujejo deduktivni pristopi, kar je za analitično naravo tega prispevka ustrezneje.

\section{KRATEK PREGLED POLITIČNO-TERITORIALNIH PROCESOV NA BALKANSKEM POLOTOKU}

Današnje politično-teritorialne enote na Balkanskem polotoku imajo vse po vrsti dokaj staro preteklost. Medtem ko nekatere iščejo svoj zgodovinski izvor že globoko v antiki, dolguje glavnina današnjih držav svoje ime zlasti srednjeveškim fevdalnim tvorbam. Ozemlja so tedaj dobila svoja imena, obseg pa se je zaradi pogostih poznejših sprememb in pa oblikovanja modernih narodov od nekako 18. st. dalje precej zameglil. Toda v realnosti ne srečamo prav redko sklicevanja na 'zgodovinsko' pripadnost določenih ozemelj izbrani državi narodu. Jezikovno-kulturna sorodnost je tu realno igrala sekundarno vlogo, čeprav so se nacionalizmi balkanskih narodov vselej radi sklicevali nanjo. Prepletanje etnično-kulturnih elementov na eni ter teritorialno-pravnih principov na drugi strani je v moderni dobi ustvarjalo zapleteni gordijski vozel odnosov, ki so tudi zaradi sorazmerno močnih tujih vplivov v nekaterih obdobjih sprožali turbulentne procese $\mathrm{z}$ nepredvidljivimi, in vsaj za domače prebivalstvo, tragičnimi posledicami. Razhajanja med teritorialno zaznavo 'svojega' oziroma 'našega' ter etnično realnostjo že sama po sebi sprožajo vsaj nekaj konfrontacij, če ne že odprtih konfliktov. Kljub težnjam, da bi v fazah oblikovanja in širjenja nacionalnih držav zajeli večino ali vse 'svoje' prebivalstvo (kakršen je primer Makedoncev; Zupančič 2006a, 126-128) in bi bile te države tudi narodno homogene, se je dogajalo prav nasprotno. Teritorializacija etničnih skupnosti se je zaradi izrazito etnično in versko mešane sestave prebivalstva pogosto končala s stadijem nacionalne države s sorazmerno številčnimi in kompaktno naseljenimi manjšinami. Ob tem ne gre prezreti dejstva, da so na oblikovanje po- 
litičnih meja bistveno vplivale tudi zunanje sile. Meje so torej v znatni meri tudi 'dediščina' mednarodnih odnosov.

Da bi pojasnili razmerje/odnos med etničnostjo in teritorialnostjo Balkanskega polotoka, se je treba vsaj na kratko podati v čas nastajanja novih nacionalnih držav na tem prostoru. To je čas 18. in predvsem 19. st., ko sta se mnogonarodna imperija (habsburški in otomanski) pričela strukturno in ozemeljsko spreminjati. Poglavitni dejavnik pri tem so bili nacionalizmi narodov (na splošno v Evropi), ki so jih vstaje in upori ter oblikovanje teritorialnih avtonomij in pozneje neodvisnih držav potegnili iz anonimnosti politične zgodovine. Pri tem so se rastoči nacionalizmi pogosto sklicevali na stare (praviloma srednjeveške) zgodovinske entitete. Medtem ko se je v obdobju splošnega narodnega preporoda v Evropi tiste dobe zdelo sklicevanje na pravico do združevanja vseh ozemelj s kompaktno poselitvijo nekega naroda samoumevno (Hobsbawm 2004, 59-67), so poznejše ambicije teritorialnega širjenja posegale po 'zgodovinskih' argumentih (npr. obstoj stare srednjeveške države). Nacionalni miti se sicer niso ujemali z etnično realnostjo, a so se dobro prilagajali geopolitiki mladih nacionalnih držav, ki jim je bilo širjenje državnega ozemlja eden najpomembnejših strateških ciljev. Toda pomembno mesto so imele tudi vsakokratne administrativne meje; mnogim pokrajinam so dale ime in (poznejše politične) meje.

Značilen primer je Bosna in Hercegovina. Zaradi specifičnih domačih razmer se je islam tam močneje utrdil in Bosna je postala najzahodneje ležeče stabilno turško ozemlje na evropskih tleh. Po višku moči otomanskega imperija v 17. st., ko je dosegel največji ozemeljski obseg (Atlas evropske zgodovine 1996, 120-130), je turška vojaška moč pričela pešati. Do leta 1683 je obsegala večino Panonske kotline in Transilvanije in, razen malih beneških posesti v Dalmaciji, na Kreti in nekaterih grških otokih ter ozemlja Dubrovniške republike, tudi celoten Balkanski polotok. Omenjenega leta se je s porazom turške vojske pred Dunajem pričelo ozemeljsko krčenje otomanskega imperija, ki je v naslednjih treh desetletjih izgubil skoraj vso Panonsko nižino in za krajše obdobje tudi severno Srbijo (Magocsi 2002, 63-66). Ozemlje je pripadlo ogrski kroni, dejansko pa rastočemu habsburškemu cesarstvu, ki je s tem postalo tudi etnično in kulturno najbolj pestra evropska država (Taylor 1956, 24-35). Burni procesi premikanja političnih meja so sprožali velike selitvene tokove. Precej izpraznjen južni rob Panonske nižine severno od Donave in Save so pričeli načrtno naseljevati z raznorodnimi kolonisti. Med njimi je bilo precej Srbov, ki so se umikali zlasti iz južnejših predelov, še posebej z območja Kosova. Na današnjem Hrvaškem ter v Vojvodini so oblikovali Vojno krajino, ozemlje s posebnim statusom (Magocsi 2002, 67). Funkcija tega ozemlja je bila še dolgo potem klasično mejišče med imperiji (Tunjić 2004, 72). Predstavljala je torej 'antemurale cristianitatis' (branik krščanstva) v vojaško-političnem smislu še vsaj stoletje potem (Tunjić 2004, 146), v politično-teritorialnem pa vse do avstrijske okupacije Bosne in Hercegovine (1876) ter njene aneksije (1908). Bosna je ostala ozemeljsko nespremenjena tudi potem, ko so se pričeli v 19. st. osamosvajati Srbi, Črnogorci, Romuni, Bolgari in Grki.

V ozemeljsko spreminjanje politične karte Balkanskega polotoka so bistveno posegale tudi tuje sile in pomembno prispevale k politični teritorializaciji posameznih etničnih skupin. Proces osamosvajanja balkanskih narodov je zato združeval tako notranje kakor zunanje sile. Slednjim je bil 'bolnik ob Bosporju' - kakor so radi imenovali turški imperij zaradi vse večje upravne in gospodarske, pa tudi vojaške kaotičnosti - pač primeren cilj za dosego 
lastnih strateških interesov. Črnogorci so odlično izrabljali prednosti goratega kraškega ozemlja in tako dosegli že v 18. st. dejansko, ne pa tudi formalne neodvisnosti (Zgodovina narodov Jugoslavije 1959, 1057-1085). Leta 1804 je prvi srbski upor v Beograjskem pašaluku² prerasel v narodno gibanje, v katerega so se posredno vključevali tudi Srbi iz Vojne krajine. Izjemnega pomena je bil pritisk carske Rusije, ki je proti Turčiji sprožila dve vojni (1806 in 1809).

Morebitni večji ruski vpliv na dogajanje v osrčju Balkana je preprečil leta 1812 sklenjeni mir v Bukarešti. Rusija se je morala soočiti z močno francosko (Napoleonovo) invazijo. Že naslednje leto je zato sledila ponovna turška zasedba osvobojenih srbskih ozemelj. Leta 1815 je prišlo do drugega srbskega upora, ki je po dveh letih privedel do avtonomije znotraj otomanskega imperija (Hupchick in Cox 2001, 25). Obenem je poraz Napoleonove armade proti Rusiji slednji dal precej poleta in povečal ruske strateške interese. Iskanje prostega izhoda na topla morja je usmerjalo rastočo evrazijsko velesilo proti jugu. Toda pot prek Črnega morja in Bosporja, Dardanel ter grških otokov je vodila prek turških ozemelj in tudi morske prehode je bilo enostavno nadzorovati. Turčija je torej teritorialno zapirala ruske prometne in strateške aspiracije proti odprtim sredozemskim vodam. Iskanje zaveznikov na Balkanu je zato imelo svojo širšo logiko, ki vse do danes ni izgubilo svojega pomena.

Ruski vpliv se je po kongresu Svete alianse (1821 v Ljubljani) še okrepil. Še istega leta je prišlo na Peloponezu do grške vstaje, ki bi se po začasnih uspehih kljub mednarodni pomoči prostovoljcev verjetno končala s porazom. Toda intervenirale so francoske, britanske in ruske sile, kar je po nekaj letih pripomoglo k popolni neodvisnosti Grčije leta 1830. Srbija je postala napol neodvisna kneževina: dovolj za oblikovanje lastne ozemeljske politike. Rusija se je s protektoratom nad Vlaško in Moldavijo (1829) pomembno približala jugu, ni pa dosegla ključnih strateških ciljev: da bi sama ali prek zaveznikov osvojila obale odprtega morja. Njen poraz v krimski vojni (1853-56) proti združenim silam Francije in britanskega imperija je pripomogel k osamosvajanju Vlaške in Moldavije, ki sta se 1862 združili v Romunijo (Atlas evropske zgodovine 1996, 156-158). Razmeroma stalen pritisk Rusije na Turčijo je Srbiji leta 1833 omogočil razširitev njenega teritorija predvsem na jugovzhodu.

Habsburški monarhiji je slabitev Turčije sprva izjemno ustrezala. Toda nacionalna gibanja osvobajajočih se narodov Balkana so zelo hitro presegla regionalne okvire. Podobno kot druge države tistega časa, so se pričele ozirati za združevanjem vseh ozemelj, kjer naj bi prebivali pripadniki 'njihovih' narodov. Nacionalne ideologije so zato hitro trčile z interesi včerajšnjih zaveznikov. Zlasti habsburška monarhija se je pričela zavedati silne moči nacionalizmov, ki so v letih 1848 in 1849 prešli v odprta revolucionarna ${ }^{3}$ gibanja in avtonomaške politične zahteve. Že nekaj let poprej (1844) so nastale 'Načertanije' Ilije Garašanina dejansko okviri srbske zunanje politike, ki je predvidevala večanje njene moči in združevanje slovanskih narodov habsburške in otomanske države (Enciklopedija Jugoslavije 1958, 428). Možnosti širjenja so bile predvsem v predelu Bosne in Hercegovine in ozemlju severno od Save in Donave (današnji Slavonija in Vojvodina) ter proti jugu. Zadnjo smer so zagovarjali tudi s historičnimi in ne zgolj z etničnimi argumenti.

\footnotetext{
${ }^{2}$ Največja upravno-politična enota v času otomanskega imperija; vodil jo je paša.

${ }^{3}$ Dejansko je šlo predvsem za zahteve po 'narodnih' in 'kulturnih' pravicah.
} 
Bolgari so imeli težje pogoje za osvoboditev izpod turške oblasti. Ozemlje današnje Bolgarije je zaradi prevlade nizkega površja, bližine in odprtosti proti jedru turške moči Carigradu - nudilo turški vojski bistveno hitrejši in lažji dostop, zato so lokalne upore in nemire hitro zatrli. Poleg tega so več kot desetino prebivalstva sestavljali etnični Turki, ki so imeli tudi ugoden gospodarski položaj. Sorazmerno močno bolgarsko nacionalno gibanje je moralo zato počakati na ustreznejši čas. Uspeh sosedov proti turški moči je povečeval osvobodilne možnosti Bolgarije. Podobno kot v ostalih balkanskih državah je tudi tu veliko vlogo igrala (bolgarska) pravoslavna cerkev, še posebej po letu 1870, ko ji je Visoka Porta priznala avtokefalnost.

Upor leta 1876 so Turki zatrli. Zaradi krutosti si je Turčija nakopala tako rusko kakor tudi angleško in francosko nasprotovanje, ki je kmalu (1877) preraslo v vojno (Blgarite atlas - The Bulgarians Atlas 2001, 180-181 in 188-189). V tej diplomatski in vojaški igri je bilo precej preigravanja nasprotnikov. Oslabljena Rusija se je ne le zavedala turške moči, temveč se je bala tudi avstrijskega posredovanja. Tajni sporazum je zagotovil avstrijsko nevtralnost, v zameno pa naj bi Rusija podprla aneksijo Bosne in Hercegovine (ki je bila pomemben srbski cilj). V vojni je Rusija utrpela velike vojaške izgube (nad 200.000 vojakov). Toda rusko-turški mir, sklenjen v San Stefanu leta 1878, je bil za Bolgarijo kot strateško zaveznico Rusije izjemno ugoden: država je tako na en mah postala ozemeljsko največja politična tvorba na Balkanskem polotoku, izvzemivši Avstro-Ogrsko! Obsegala je ozemlja med Donavo in Egejskim morjem, celotno Makedonijo in še dele Albanije ter današnje Srbije (Stefanović in Krstić 1978). Toda bistvenega pomena - zlasti za Rusijo - je bil širok dostop do Egejskega morja. Ta 'sanstefanska' meja Bolgarije je še dolgo ostala geopolitični cilj in ideal bolgarskih nacionalnih pretenzij.

Zaradi francoskega in britanskega nasprotovanja, ki sta se zbali premočnega ruskega vpliva na Balkanu, je le nekaj mesecev kasneje še istega leta na berlinskem kongresu prišlo do bistvenih teritorialnih sprememb. Bolgarijo so zmanjšali za več kot polovico in jo omejili na ozemlje severno od Balkanskega gorstva (Stefanović in Krstić 1978). Srbija je pridobila ozemlje na jugu (dolina Južne Morave), Črna gora se je razširila proti severu in segla do morja, Avstro-Ogrska je okupirala Bosno in Hercegovino ter vojaško nadzorovala Sandžak, ostalo ozemlje pa je bilo vrnjeno Turčiji.

Vendar je bilo razpadanje turškega imperija nezadržno. Leta 1881 je Grčija pridobila Tesalijo, Bolgarija pa Vzhodno Rumelijo (Magocsi 2002, 84-85). Za Makedonijo so se pulile Grčija, Srbija in Bolgarija, kar je pozneje privedlo tudi do spopada zanjo. Leta 1908 je Avstro-Ogrska anektirala dotlej okupirano Bosno in Hercegovino in se tem še bolj zamejila možen srbski vpliv proti zahodu. V prvi balkanski vojni (1912) so zaveznice (Grčija, Srbija, Črna gora in Bolgarija) Turčijo praktično izrinile z Balkanskega polotoka; ostal jim je le še Carigrad z najbližjim zaledjem ter polotok Galipoli. Bolgarija je znova dosegla obale Egejskega morja in skoraj podvojila državno površino. Grčija se je razširila na Epir, današnjo južno Albanijo in južno Makedonijo s polotokom Halkidiko. Srbija je pridobila večino današnje (vardarske) Makedonije, večino Kosova ter Albanije. Črna gora si je s Srbijo razdelila Sandžak (Gerolymatos 2002, 195-199). Makedonski etnični prostor, ki je tedaj obsegal okrog $68.000 \mathrm{~km}^{2}$, so si razdelile Grčija (Egejska Makedonija, okrog 51 \%), Bolgarija (Pirinska Makedonija, okrog 11 \%) ter Srbija (Vardarska Makedonija, okrog 38 \%) (Tun- 
jić 2004, 251-252). Od teh ozemelj je čez pol stoletja dobil avtonomijo le 'vardarski' del (ena od socialističnih republik jugoslovanske federacije), ki je bil do prve svetovne vojne 'južna Srbija' in do druge svetovne vojne 'vardarska banovina', med drugo svetovno vojno pa so jo razdelili med Bolgarijo in Albanijo (Zupančič 2006a).

Nezadovoljstvo zlasti Grčije (ki je računala na vključitev Makedonije in južne Trakije) ter Bolgarije (pričakovanja po vključitvi predvsem Makedonije, torej ozemelj ki jih je za nekaj mesecev pridobila s 'sanstefanskim' mirom 1878) so hitro pognale v novo, tokrat medsebojno vojno. Bolgarija je bila pri tem poražena in je morala odstopiti del južne Trakije Grčiji in manjša ozemlja Srbiji. Zmedo je izkoristila tudi Romunija in pridobila južno Dobrudžo. Na območju današnje osrednje Albanije je prišlo do upora in razglasitve države. Tedaj so posegle vmes velike sile in pod močnim avstrijskim in nemškim pritiskom izsilile neodvisnost Albanije. Srbija je bila ozemeljsko blokirana pri težnjah prodora proti morju; na zahodu z avstrijsko aneksijo Bosne in Hercegovine, na jugu z oblikovanjem Albanije pod nemškim princem (le za kratek čas) (Gerolymatos 2002, 212-220). Toda nezadovoljstvo južnoslovanskih narodov v habsburški monarhiji, ki jim ni uspelo spremeniti avstrijsko-madžarske dominacije znotraj mnogonarodne habsburške monarhije v uporaben trializem (Slovenski veliki leksikon, 3. knjiga 2005, 676) ${ }^{4}$, je pomembno prispevalo k temu, da so pričeli Srbiji pripisovati vlogo 'južnoslovanskega Piemonta'.

$\mathrm{Z}$ balkanskima vojnama je bila turška dominacija na Balkanskem polotoku zaključena. Narodi, ki so si v dobrem stoletju uporov in osvobodilnih vojn oblikovali nacionalne države, so hitro prešli od etničnega k teritorialnemu principu državotvorja. Državne teritorije so širili na območja, kamor je bilo pač v vsakokratnih okoliščinah možno. Etnični, kulturni in zgodovinski 'argumenti' so imeli praviloma sekundarno vlogo. Na oblikovanje državnih ozemelj so bistveno vplivale tudi tuje sile, iščoč pri tem tudi lastne strateške koristi. Balkanski polotok je postal poligon preizkušanja moči in strategij. Veliko spremembo predstavlja še združitev Italije (1861) in Nemčije (1866; Atlas evropske zgodovine 1996, 160). S tem sta nastali dve močni državi, ki sta, tudi zaradi skromnih možnosti pridobitve kolonij na drugih kontinentih, svoje gospodarske in politične sile usmerili v labilno cono med Baltikom in jadransko-jonskim prostorom. Tako se je $\mathrm{v}$ fazi vzpona svetovnega imperializma $\mathrm{v}$ pasu med Baltikom, Jadranom, Egejskim in Črnim morjem (v dobršni meri to zajema prav geografski pojem Balkana) pričela ob boku velesil (nemškega, avstrijskega, turškega in ruskega) z vzponom nacionalizmov (beri: osvobodilnih gibanj) tvoriti labilna cona malih držav. Ta 'vmesna Evropa', kot jo v svojem delu imenuje Tunjić (2004, 11-21), je v manj kot stoletju prispevala k rušenju moči prej omenjenih imperijev; danes ni nobenega več, vsaj ne v pri-merljivi obliki. Toda jedra moči (sedaj predvsem ekonomsko-politične) so ostala skoraj prav tam, kjer so bila pred stoletjem.

Kennedy (2002, 312-317) upravičeno opozarja na rastočo moč Italije, ki je zelo hitro doumela priložnost svoje 'vzhodne' politike in jo upravičevala z zgodovinskimi (posesti Beneške republike na vzhodnem Jadranu) in še bolj kulturnimi (prisotnost italijanskih skupnostih na tem območju). Posebno mesto ima pri tem ozemlje Albanije; z njenim obvladovanjem

\footnotetext{
${ }^{4}$ Idejo o trializmu so podpirali zlasti na Hrvaškem (1894), predvsem Hrvaška stranka prava, in v slovenskih deželah (1898). To naj bi bil tretji del Habsburške monarhije, ki naj bi združeval južnoslovanske dežele pod habsburško krono, brez današnje Vojvodine.
} 
je Italija obvladovala strateški pas ozemlja ob Otrantskih vratih in sosedstvu. Zlasti vloga Nemčije je zaradi gospodarske in vojaške moči naglo narasla tudi na Balkanu. Ni naključje, da so uspeli umestiti nemške plemiške rodbine v Grčijo (1832 Otto von Wittelsbach Bavarski), Bolgarijo (1879 princ Alexander von Battenberg), Romunijo (1866 kneza Karla I. iz rodbine Hohenzollern-Sigmaringen) in Albanijo (1913 Wilhelm zu Wied) (Natek in Natek 2006, 13, 28, 58, 146). Slednji je moral že po letu dni zapustiti deželo, ki jo je vse bolj osvajal italijanski kapital. Albanija je praktično postala italijanska kolonija. Najmočnejši vpliv je Nemčija ohranila v Bolgariji, čeprav so imele nemške družbe v Turčiji vrsto koncesij in obsežnih poslov pri gradnji infrastrukture ter opremljanju vojske. Nemški vpliv se je v Bolgariji izkazoval tudi tako, da je država v prvi svetovni vojni pristopila k centralnim silam (kakor tudi Turčija!).

Do bistvenih ozemeljskih sprememb je znova prišlo po prvi svetovni vojni. Avstro-Ogrska je po vojaškem porazu klonila in razpadla. Na njenih ruševinah sta se oblikovali novi večnacionalni državi Češkoslovaška in Jugoslavija, Romunija se je ozemeljsko podvojila, Italija je pridobila ozemlja v Alpah in na vzhodni obali Jadrana, Poljska pa južne predele in del Galicije. Nekdanji jedri monarhije, torej Avstrija in Madžarska, sta postali klasični nacionalni državi s pestro etnično sestavo (številnimi manjšinami; zlasti Madžarska), medtem ko sta zunaj državnih okvirov pustili zelo številčne nemške in madžarske skupnosti. Tako se je konfliktni potencial v večini držav še povečal.

$\mathrm{V}$ težnjah po doseganju čim višje stopnje etnične homogenosti so bile manjšine tarča načrtnih in neredko nasilnih asimilacijskih poizkusov (Mazower 2002, 51-76). Fazi vojaške in diplomatske osvojitve ozemlja je sledila etnična homogenizacija oziroma notranja integracija. Zaostrovanje odnosov med Turčijo in Grčijo je privedlo do vojne, ki se je končala 1923 z novimi mejami in množičnim eksodusom Grkov iz Male Azije ter Turkov iz Grčije, predvsem iz južne Trakije. Pomembna zunanja sila je postala Italija. Prisvojila si je Dodekaneško otočje in gospodarsko skoraj v celoti obvladovala Albanijo.

Politični zemljevid Balkanskega polotoka je bil po prvi svetovni vojni radikalno spremenjen. Največji del sta zavzemali Romunija in Kraljevina SHS, državi torej, ki sta bili izrazito 'sestavljeni' in zato labilni. Turčija je bila potisnjena povsem na rob in omejena na Malo Azijo in Vzhodno Trakijo. Rusija se je zaradi uvedbe socializma znašla v mednarodni osami in je prenehala biti vpliven strateški dejavnik na Balkanu. Avstro-Ogrske ni bilo več in tudi nemški vpliv je po porazu v prvi svetovni vojni v tej regiji začasno prenehal. Srbiji je z združitvijo južnoslovanskih narodov od Triglava do Vardarja uspel velik geopolitični podvig. Dejansko je odigrala vlogo regionalnega povezovalca in postala nesporna regionalna sila, poleg prav tako multietnične Romunije.

Toda konfliktni potencial novonastalih držav je bil izjemen. Značilen je primer Jugoslavije. Sprememba imena iz Države SHS v Kraljevino Jugoslavijo (1929) zelo nazorno kaže, da je začetne elemente vsaj delnega parafederalizma hitro zavrgla in pričela siliti v unitarizem. Tako se je pojav Jugoslavije pričel predstavljati kot 'močna Srbija', ki se je morala takoj na začetku spopasti s partikularizmi posameznih narodov. Medtem ko je slovenski spričo relativno skromne moči lahko vplival predvsem kot jeziček na tehtnici notranjepolitičnih odnosov, je hrvaški pričel tvoriti krepko opozicijo in slednjič bistveno prispeval k upravni asimetriji prve Jugoslavije (Banac 1987, 141-149). 
Uvedba nove administrativne razdelitve države na banovine, poimenovane po rekah, le potrjuje, da je bil napor v smeri notranje državne, dejansko pa predvsem etnične integracije poglavitna politična premisa. Koncept 'troedinega naroda' v enotni jugoslovanski državi je zanikal bosansko-muslimansko, makedonsko, črnogorsko in tudi albansko identiteto (Klemenčič in Žagar 2004, 101-115), prav tako pa je bilo malo posluha za probleme številčne italijanske, madžarske in nemške manjšine (Biber 1966, 11-56). Čeprav je bila marginalizacija manjšin na splošno razširjena praksa v Evropi tiste dobe, je verjetno precej prispevala k radikalizaciji manjšinskih nacionalizmov. Izstopal je zlasti nemški, ki je bil zato tudi bolj dovzeten za naslonitev na nacistično ideologijo (Klemenčič in Žagar 2004, 121). Mednacionalna nasprotja so se stopnjevala. Leta 1939 je z bil oblikovanjem posebne 'Banovine Hrvatske', ki je združevala večino območij s pretežno hrvaškim prebivalstvom, unitarni model upravljanja države okrnjen (upoštevati je treba tudi sorazmerno etnično homogenost Dravske banovine s slovenskim prebivalstvom; Klemenčič in Žagar 2004, 121). Dejansko je tedaj že mogoče razpoznati obrise etnične polarizacije prve Jugoslavije na relativno homogeni slovenski (s številčno nemško manjšino) in hrvaški del (s številčno italijansko, nemško in srbsko skupnostjo) ter ostali - srbski del, ki pa je bil etnično izrazito heterogen (bosanski in sandžaški muslimani (danes Bošnjaki), Črnogorci, Makedonci, Albanci, Madžari, banatski Nemci; če se omejimo le na najštevilčnejše etnične skupnosti). Tvorba ni zdržala nacifašističnega pritiska leta 1941. Okupacija in razkosanje Jugoslavije s strani Nemčije, Italije, Madžarske in Bolgarije je za nekaj let povsem spremenilo politični zemljevid tega dela Evrope. Območja, naseljena z albanskim prebivalstvom, so se priključila 'veliki’ Albaniji pod italijanskim nadzorom in upravo (Klemenčič in Žagar 2004, 155). Po zahtevah Prizrenske lige iz leta 1878 je bila to prva politična tvorba, ki je približno pokrivala ozemeljske težnje političnega združevanja albanskega življa.

Po drugi svetovni vojni je zopet prišlo do bistvenih ozemeljskih sprememb. Romunija je izgubila vzhodno Moldavijo (Besarabijo) in Bukovino, Jugoslavija pa je pridobila ozemlja Istre, slovenske Primorske in nekaj ozemelj na vzhodni obali Jadrana. Ostale meje so ostale nespremenjene. Obenem se je v prvih povojnih letih odselila večina Italijanov (Klemenčič in Zupančič 2004), deportirali pa so tudi večji del nemškega prebivalstva iz mest in Panonske nižine (Magocsi 2002, 189-193). Obstajali so tudi načrti o selitvi Madžarov, ki pa se niso uresničili (Kocsis in Kocsis-Hodosi 1998).

Pač pa se je v jeku nastopajoče hladne vojne povsem spremenilo razmerje moči. Razen v Grčiji se je v vseh državah Balkanskega polotoka uveljavil socialistični družbeni red z enopartijsko politično strukturo ter državno-planskim gospodarstvom. Razen Jugoslavije, ki se je kmalu (1948) uprla sovjetskemu modelu družbenopolitičnega in gospodarskega ustroja, so socialistične sosede postale sovjetski sateliti. Posredno se je torej ruski (tedaj pač nazivno sovjetski) geopolitični vpliv v tej regiji izjemno povečal. Prav zaradi jugoslovanskega ekskurza v samoupravni socializem pa je bil končni geopolitični izplen sovjetskega pritiska bistveno skromnejši. Iz tega okvira sta se pozneje izvili še Romunija (1968) in Albanija (1961), vendar sta obe končali kot povsem izolirani državi. V sovjetski federaciji je bila nekdanja vzhodna Moldavija razglašena za republiko, Moldavci (Romuni) pa za samostojen narod.

Jugoslavija je prav tako uvedla federativno ureditev. Razmejevanje med republikami ni bilo enostavno. Razen Bosne in Hercegovine, ki je z izjemo majhnega ozemlja pri Herceg- 
novem (sedaj v okviru Črne gore) zadržala svoje stare (dejansko še 'turške') meje, je bila drugod potrebna vrsta kompromisov. Pri tem je bila etnična sestava prebivalstva le eno od razmejitvenih meril, ki ga niso dosledno upoštevali, čeprav naj bi z oblikovanjem republik zadostili prav potrebam etnično emancipiranih narodov. Analitiki so ocenjevali jugoslovansko federacijo kot zgleden primer ureditve medetničnih odnosov večnarodnih držav (SetonWatson 1977, 148). Znotraj Srbije so oblikovali dve enoti: Avtonomno pokrajino Vojvodino in Avtonomno območje Kosmet. Omejitev je le okvirno upoštevala etnično razporeditev prebivalstva. Vendar notranje meje v okviru tedaj trdne jugoslovanske federacije, ki je razglašala 'bratstvo in enotnost' kot eno ključnih vrednot, niso predstavljale resnega problema. Avtonomno območje Kosmet je leta 1963 spremenilo svoj status in postalo Avtonomna pokrajina Kosovo in Metohija. Leta 1969 so ime poenostavili v SAP Kosovo, kljub nasprotovanju srbskega prebivalstva. ${ }^{5}$

Z ustavno reformo leta 1974 je Kosovo pomembno okrepilo svoj položaj. Predvsem je naraščajočemu deležu albanskega prebivalstva dalo možnosti oblikovanja nacionalnih institucij. Zaradi vse močnejših pritiskov na eni ter realne populacijske in tudi (prikrite) ekonomske moči albanskega prebivalstva se je albanski nacionalizem stopnjeval. Leta 1981 so se začeli odprti konflikti in upori albanskega prebivalstva. Leta 1989 je bila avtonomija obeh pokrajin formalno ukinjena (Klemenčič in Žagar 2004, 197-213). Federacija je tonila v vse večjo politično in gospodarsko krizo. Ker se je tedaj (1989-91) sesul tudi socialistični družbeni red v praktično vseh evropskih državah, je jugoslovanska federacija doživela kolaps. $\mathrm{V}$ naslednjem desetletju je sledila nova faza intenzivnih politično-teritorialnih sprememb z oblikovanjem novih nacionalnih držav na ozemlju nekdanje Jugoslavije. Osamosvojitev Kosova je zadnje dejanje tega burnega procesa.

Razkroj Jugoslavije je treba gledati tako iz njene notranje (strukturne) kakor tudi širše geopolitične perspektive. Po razpadu vojaško-politične bipolarnosti sveta in socialističnih družbenih ureditev (zadržala se je le na Kitajskem, v Severni Koreji, Vietnamu ter na Kubi) so se večetnične države začele razkrajati. Češkoslovaška se je razdelila na Češko in Slovaško, Sovjetska zveza se je ob nekaj lokalnih vojnah prav tako (razmeroma!) sporazumno razdelila; ostri konflikti na območju Kavkaza in Srednje Azije pa imajo poleg domačih napetosti tudi širše razloge. Razkroj Jugoslavije pa je bil dramatičen in poln konfliktov. Toda ob tem ne gre pozabiti tudi številnih regionalističnih gibanj v Evropi, ki so prav tako pripeljala do notranjih upravnih sprememb (unitarna Belgija je postala federacija, Španija je z regionalizacijo vsaj do neke mere zadostila nacionalnim težnjam Kataloncev, Baskov in Galicijcev ipd.). Obenem je Evropska gospodarska skupnost prehajala v novo obliko združene Evrope - Evropsko unijo (1992). Tako se je stari kontinent znašel v fazi naglih in velikih politično-teritorialnih sprememb, ki so vsekakor imele določen odmev tudi na Balkanskem polotoku.

Medtem ko je Slovenija zapustila jugoslovansko federacijo po krajši vojni, je sosednja Hrvaška preživela štiri leta hudih spopadov. Na območjih z večjo prisotnostjo srbskega prebivalstva so se oblikovale 'krajine', ki so oblikovale tudi nekatere organe začasne oblasti (Tanner 1997, 222-224). Podobne tvorbe zasledimo tudi na drugih kriznih območjih v tem obdobju (Zupančič 2006b). Obenem se je spremenil tudi način reševanja konfliktov. Name-

\footnotetext{
5 Albanci imenu Metohija nasprotujejo; zanje je to Dukagjin.
} 
sto preprečevanja širjenja spopadov in diplomatskih dogovorov se je uveljavljal koncept mednarodnega intervencionizma (primer Kuvajta oziroma Iraka je bil dovolj zgovoren) in teritorialne rekonstrukcije. Vendar je imel OZN kot formalno ključni dejavnik čedalje manjši vpliv. Namesto tega so se uveljavile druge sile, kar lepo razgalja geopolitično geometrijo na prelomu tisočletja. V teritorialno strukturo sedaj posegajo skupine držav, ki imajo do teh teritorijev določen strateški interes. Prav kriza nekdanje Jugoslavije ter načini in oblike reševanja krize kažejo, da je Balkanski polotok postal (ali ostal) presečišče interesov, zato pa tudi polje spopadov, kjer se srečujejo lokalni in globalni 'igralci'.

Teritorialne spremembe so posledica in indikator teh burnih procesov. Čeprav je šlo pri vseh kriznih območjih na območju nekdanje Jugoslavije za medetnične vojne in obenem tudi spopade za ozemlje in življenjske vire, so bili koncepti reševanja s strani mednarodnih dejavnikov dejansko zelo različni. Na Hrvaškem so še prevladovali stari načini: mednarodne sile so torej zgolj preprečevale širjenje spopadov, v rekonstrukcijo države pa se niso spuščale. Krizo so razrešile hrvaške sile same in v dveh ključnih vojaških operacijah osvobodile državni teritorij (Hofbauer 2001, 43-45). Po nekaterih virih naj bi hrvaški vojski pomembno pomagala ameriška vojska (Pirjevec 2003, 418).

V Bosni in Hercegovini je bilo drugače. Zapletene okoliščine spopadov vseh proti vsem ter oblikovanja začasnih lokalnih zavezništev so skušali mirovni posredniki urediti s koncepti regionalizacije in kantonizacije. Ta logika, ki izhaja iz podmene o miroljubnosti etnično homogenih ozemelj, se je torej-kako ironično! - prijela tudi arhitektov novega postkonfliktnega bosanskega zemljevida. Banac (2006, 31-33) se upravičeno sprašuje, ali so diplomati sploh imeli možnost izbire, saj se jim je nepregledni bosanski etnični in verski mozaik spreminjal in ustvarjal nepredvidena lokalna zavezništva. Razmeroma močne mednarodne sile so bile pri ščitenju ogroženih skupin prebivalstva neuspešne in pogosto tudi nemočne. Nepregledno medetnično vojno so prekinile šele ZDA leta 1995 in z daytonskim mirovnim sporazumom vsilile koncept sedanje dvostopenjske asimetrične federacije.

Tako je bilo zadoščeno mednarodni politiki (praksi), ki se je v Evropi uveljavila po letu 1974: tezi o nespremenljivosti političnih meja. Bosna in Hercegovina je tako ohranila zunanji okvir (mejo iz leta 1991), notranje politične meje (ki so tudi varnostno in ekonomsko nadzorovane) pa so se dejansko prilagodile novi etnični situaciji in črti spopadov (Burg in Shoup 2000). Žal pa je ta salomonska odločitev pripeljala do pat pozicije in gospodarske neuspešnosti Bosne in Hercegovine, ki je značilen primer zapletenega in dragega regionalnega upravljanja.

Zopet drugačen koncept reševanje so mednarodni dejavniki ubrali v Makedoniji. Po spopadih leta 1998 in predvsem 1999 na Kosovu, ki mu je sledila vojaška akcija zveze NATO proti Zvezni republiki Jugoslaviji, je sledil upor Albancev v zahodni Makedoniji. Večmesečni spopadi spomladi 2001 so zahtevali nad 200 življenj in precej materialne škode (Smith 2003, 57). Makedoniji je vojaško pomoč ponudila le Bolgarija, zahodne sile, že dobro zastopane v mirovni misiji UNMIK na Kosovu, pa so od obeh strani zahtevale prekinitev spopadov in začetek pogajanj. Sklenjen je bil t.i. ohridski sporazum, po katerem imajo Albanci v Makedoniji pravico do tretjinske participacije v državni administraciji. Albanci formalno niso dosegli teritorialne avtonomije v zahodni Makedoniji, dejansko pa imajo realen nadzor nad tem ozemljem, saj nadzirajo vse ključne gospodarske, izobraževalne in tudi politične vzvode 
oblasti na lokalni ravni. Pri tem so bili pritiski, zlasti EU, na Makedonijo zelo močni; deloma so s tem celo pogojevali pričetek pogajanj o vključevanju Makedonije v EU (Lovenjak 2006). Makedonija je torej izrazito regionalizirana in prek 'etničnih' vprašanj dejansko podrejena močnim vplivom iz sosedstva (Tunjić 2004, 252-253).

Primer Kosova je povsem specifičen, čeprav se časovno in prostorsko tesno navezuje na proces disolucije jugoslovanske federacije in medetničnih spopadov za ozemlje. Toda albanski manjšinski nacionalizem je izvorno starejši in sega vse v dobo od zaključkov druge balkanske vojne dalje. Jugoslovanska federacije je z omejeno avtonomijo Kosova (1974) le deloma izpolnila državnostna pričakovanja Albancev, ki so poleg tega imeli - sicer nadvse nezavidljivo situacijo - samostojno državo v sosedstvu. Odprt konflikt se beleži kontinuirano od leta 1981 dalje in je bil po svoje preludij v jugoslovansko politično in gospodarsko krizo. Vendar do širših spopadov v obdobju največje vojaške intenzivnosti med leti 1992 in 1995 vendarle ni prišlo.

Kosovski Albanci niso oblikovali posebnih osvobojenih ozemelj (etničnih enklav) kot se je to dogajalo na Hrvaškem in v Bosni in Hercegovini, temveč so sledeč izkušnjam urbane in ruralne gverile oblikovali tajno vzporedno oblast, ki je zajemala praktično vse družbene sfere na celotnem interesnem ozemlju in tudi izven njega. Do izrazite teritorializacije je prišlo šele ob prelomu tisočletja. V enklavah so se znašli Srbi, ko so po napadu zveze NATO in odhodu srbske policije in vojske ostali sami. Status quo pod upravo UNMIK-a je vztrajal nekaj let in ni zadovoljeval nikogar. Po letu 2000 je bilo Kosovo de facto že povsem ločeno od Srbije, ki je v vmesnem času izgubila tudi Črno goro (junija 2006). Po drugi strani pa ne prej UNMIK in ne sedaj EULEX ne zadovoljujeta albanskih interesov po neodvisnosti.

Toda obenem je bistveno spremenjeno tudi razmerje sil, ki se je krepko nagnilo v prid moči tujih sil na Balkanskem polotoku. Močne ruske dominacije, ki je bila prek socialističnih režimov prisotna $\mathrm{v}$ obdobju hladne vojne, praktično ni več. Edini vzvod ruske moči so projekcije poteka plinovodov prek Črnega morja (Južni tok). Prav tako ni več politično in vojaško močnih držav v regiji sami. Vzpostavlja se ravnovesje med regionalnimi dejavniki in sorazmerno močnimi mednarodnimi silami (vojaškimi in civilnimi) v srednjem delu Balkanskega polotoka. Med Bosno in Hercegovino na zahodu ter kosovsko-makedonskim prostorom na vzhodu je vezni člen prav tako multietnična pokrajina Sandžak v sklopu Srbije. Z vstopom Romunije in Bolgarije v Evropsko unijo in NATO (2007) ter pridružitev Albanije in Hrvaške severnoatlantskemu zavezništvu (2009) se je oblikovalo zavarovanje vzhodnega loka Jugovzhodne Evrope, s čimer se je praktično onemogočil ruski strateški vpliv v tej regiji. EU je jasno nakazala smeri nadaljnje širitve tudi na preostali del Balkanskega polotoka. Videti je, da ima EU aspiracije po krepitvi in naposled popolni prevladi nad Balkanom, ne nazadnje tudi zaradi strateške vrednosti ozemlja, prek katerega bo morala EU izboljševati nezavidljivo bilanco energetske oskrbe. Pojem 'Zahodni Balkan' je tako povsem operativnega značaja. Zato pri podpori novonastali državi Kosovo s strani ZDA in tudi ključnih evropskih držav ne gre toliko za reševanje kriznega območja, temveč predvsem za spreminjanje strateških razmerij. 


\section{MORFOLOŠKA, STRUKTURNA IN FUNKCIJSKA ANALIZA POLITIČNEGA ZEMLJEVIDA BALKANA}

\section{I. O obliki in ustroju držav Balkanskega polotoka}

Rezultat teritorialnega drobljenja, ki so ga nekateri zajedljivo imenovali ‘balkanizacija’ je nastanek majhnih držav. Te sedaj, po razpadu jugoslovanske federacije, odločno prevladujejo. Če pri tem upoštevamo še bližnje sosedstvo, torej Slovenijo (že zaradi njene 70-letne vključenosti v jugoslovansko državo), Moldavijo (zaradi njene prebivalstvene sestave in sorodnosti z Romunijo) in Cipra (prav tako zaradi njegove grško-turške etnične sestave in de facto politične razdeljenosti), je to zanesljivo politično-teritorialno najbolj razdrobljen del Evrope. Relativna 'mladost' držav in njihova majhnost (v primerjavi z ostalimi deli Evrope) je ključna poteza Jugovzhodne Evrope alias Balkana. Po obsegu državne površine je najmanjše Kosovo, takoj pa mu sledi Črna gora, ki je najmanjša po številu prebivalstva. Makedonija in Albanija sta naslednji mali državi, katerima sledita Bosna in Hercegovina ter Hrvaška, nato pa Srbija. Vse te države imajo manj kot $100.000 \mathrm{~km}^{2}$ površine in manj kot 10 mil. prebivalcev, kar jih glede na evropske okvire uvršča med male države. Bolgarija je na meji z okrog $111.000 \mathrm{~km}^{2}$, a krepko pod 10 mil. prebivalcev (7,7 mil.), kar jo postavlja ob bok Srbiji. Iz tega konteksta povprečja izstopata le Grčija $\left(131.000 \mathrm{~km}^{2}\right.$ in 11,1 mil. prebivalcev, predvsem pa Romunija z $238.000 \mathrm{~km}^{2}$ in 21,6 mil. prebivalcev (Fischer Weltalmanach 2009). Pri tem je treba upoštevati, da je razdrobljenost dejansko večja, saj je Bosna in Hercegovina dvostopenjska federacija z zelo skromnim učinkom osrednje zvezne oblasti, Kosovo pa dejansko razdeljeno na albanski (velika večina) in srbski del (enklave; največja in dovolj posebna je tista s Kosovsko Mitrovico, ki se teritorialno naslanja na Srbijo). Poleg tega sta Bosna in Kosovo pod nadzorom mednarodnih sil, torej dejansko neke vrste protektorata. Makedonija je de facto razdeljena na pretežno (in čedalje bolj izključno) albansko zahodno Makedonijo, znotraj katere vztraja makedonski etnični otok pri Mavrovu. Podobne značilnosti imata tudi dve državi v sosedstvu: Ciper je razdeljen na samooklicano Turško republiko severni Ciper in grški del, ki pa je nosilec in predstavnik v mednarodnem svetu enotne države. Tako je tudi v Evropski uniji zastopan kot celota, realno pa sodeluje le večji grški del otoka. Moldavija je razdeljena poleg glavnega moldavskega dela še na dve enoti: osamosvojeno Pridnestrsko republiko (ki sta jo priznali le Rusija in Ukrajina) ter Gagauzijo, ki je po agoniji nekajletne oklicane samostojnosti pristala na ponovno vključitev v državne okvire Moldavije in ohranila visoko stopnjo avtonomije.

Klasična politična geografija je precej poudarjala obliko državnega ozemlja, še bolj pa njegovo strukturo; teritorij je preprosto pomenil zelo močno dominanto, ki pomembno, če ne odločujoče vpliva na razvojne možnosti držav (Ratzel 1896; v Matznetter 1977). Danes je to manj pomembno, saj so precej v ospredju organizacijski, tehnični, ekonomski in vojaškopolitični vidiki zmožnosti družb za 'obvladovanje' posebnosti določenega ozemlja (Johnston 1982; Glassner 1993). Torej moramo veliko bolj upoštevati infrastrukturno povezanost različnih območij države v soodvisno, harmonično celoto. S tega vidika so lahko opazne regionalne razlike element destabilizacije, ne glede na njihov vzrok. Pojav šibkih držav lahko štejemo za začetek destrukcije (Krastev 2004, 106). Ta element je še posebej pomemben pri 
odprtih mejah, kjer skorajda ni več bistvenih ovir gravitacijski moči središč v sosednjih državah. Odprte meje namreč omogočajo uresničevanje strategij, kjer lahko prek različnih politik (npr. prostorskega razvoja, prometne politike), pa tudi zaradi velikosti in upravne moči administrativnih enot pomembno vplivajo na območja v sosednjih državah. Potemtakem politično-teritorialne spremembe v združeni Evropi niti niso več potrebne, nadomestiti jih je mogoče $z$ elementi večje medregionalne kohezije. V tej luči imajo ambicije t.i. 'evroregij' določeno geopolitično konotacijo, neredko celo pretenzije po raznovrstni in končno torej tudi politični dominaciji.

Analizo kohezivnosti državnih ozemelj je smiselno povezati še s pregledom razmerja med centralnimi in perifernimi območji. Pri tej analizi smo uporabili nekatere indikatorje demografskega razvoja (gostoto poselitve, delež urbanega prebivalstva oziroma navzočnost večjih urbanih središč; trend selitvenih gibanj, stopnjo terciarizacije in podobno). Podatke smo pridobili v statističnih pregledih (nacionalne statistike preučevanih držav, nekateri tematski atlasi ipd.), procese pa preverili in določili s pomočjo različnih geografskih analiz v literaturi. Zaradi precejšnjih razlik v zajemu podatkov je enotne indikatorje skoraj nemogoče prikazati. Posploševanje je bilo torej nujno, da smo lahko balkanski prostor conirali v centralna, periferna in vmesna območja ter posebej izpostavili ključna razvojna jedra. Večinoma jih res predstavljajo državne prestolnice ter velike aglomeracije, prav povsod pa temu ni tako. Ob tem smo posebej upoštevali tudi element maritimnosti, ki daje državi določene strateške in razvojne prednosti. V splošnem govorimo o maritimni državi kot tisti, ki ima stik s svetovnim morjem, vendar to samo po sebi ni dovolj. Podobno kot pri goratosti (ki jo dostikrat opredeljujemo kot element geografske prikrajšanosti), pa je ključna izraba teh elementov, predvsem s prometnimi in drugimi oblikami infrastrukture. Opredelitev je opisna.

Balkanski polotok obliva pet morij in s tega stališča bi morala maritimnost preučevanih držav izstopati. Obale vzhodnega Jadrana in celotnega egejskega akvatorija so zelo razčlenjene in s številnimi otočji: kvarnerskimi in dalmatinskimi v Jadranu, jonskim v Jonskem morju ter Kikladi in Sporadi v Egejskem morju, ki ga na jugu zaključuje Kreta, eden večjih evropskih otokov. Vendar je zaradi velike goratosti obmorsko zaledje večine vzhodne jadranske obale zelo skromno. Alpidska orogeneza je v nizu Dinarskega gorstva oblikovala niz orografskih pregraj, ki se od Slavnika in Učke ter Snežnika z Gorskim kotarjem sklenjeno nadaljujejo v verigo Velebita, ta pa z nekaj odmika v severni Dalmaciji nadaljuje v Dinaro in ostale nize nad $1000 \mathrm{~m}$ visokih sredogorskih hrbtov, od katerih se najvišje vzpnejo Biokovo v srednji Dalmaciji ter Orjen in Rumija v Črni gori.

Ti t.i zunanji Dinaridi so skoraj v celoti zgrajeni iz apnencev in dolomitov, na katerih se je razvilo eno najobsežnejših sklenjenih kraških območij Evrope. Nizi tektonsko zasnovanih gorskih hrbtov se izmenjujejo z enako usmerjenimi podolji, v katerih so se oblikovala obsežna kraška polja. Tudi dalmatinski otoki večinoma dosledno sledijo dinarski tektonski smeri. Zaradi vzdolžne smeri predstavljajo Dinaridi opazno pregrajo tako na kopnem kakor tudi na morju. Zaradi kraškega in močno razčlenjenega površja je poselitev zaledja skromna in tudi ob obalah prevladuje drobnonaselbinski koncept.

Tudi egejski akvatorij objema visoko zaledje Šarsko-Pindskega gorstva in Rodopov. Toda doline se precej širše odpirajo proti morju in zato tvorijo v obalnih predelih obsežnejše ravnice. S tega stališča je ta del torej že po naravi predisponiran za gostejšo naselitev na obali. 
Toda lega na jugu Balkanskega polotoka nekoliko zmanjšuje možnosti oblikovanja širših kopenskih zaledij. Po drugi strani pa je lega nekaterih ključnih grških obalnih mest izjemno ugodna v širšem makroregionalnem kontekstu. Solun leži na širokem ravnem izteku doline Vardarja, ki tvori tu široko Solunsko polje. Bližina prometnega koridorja, ki poteka po dolini Morave in Vardarja in naprej proti Atenam, nedvomno povečuje urbano vlogo drugega največjega grškega mesta.

Lega Aten je - kljub navidez robni kopenski legi - dejansko prvovrstna, saj je vpeta med grško celino in polotok Peloponez in s tem na križišče morskih poti, ki vodijo od črnomorskega prek egejskega k sredozemskemu in jadranskemu akvatoriju. Poleg tega so Atene postavljene dejansko v središče Grčije, če upoštevamo lego na široko razpršenih grških otočij. Grčija je torej edina zares učinkovita maritimna država tega dela Evrope. Vrh vsega so se Atene zaradi posebnosti zgodovinskega razvoja - poleg Carigrada - razvile v največje urbano središče Balkanskega polotoka. Turistična privlačnost celotnega egejskega območja vključno s turško obalo - je pomembno pripomogla k povečevanju letalskega prometa in s tem atenskega letališča. Atene tako privabljajo prometne tokove in s tem posredno povečujejo tudi pomen in vlogo vardarske prometnice ter Soluna kot prometnega vozlišča.

Najobsežnejšo obalno ravnino ima Albanija. Razvila se je na obilnih nanosih rek, ki pritečejo iz bližnjih albanskih gora. Albanska obala je nizka in je bila prvotno skoraj v celoti močvirna ter zato redko naseljena. Drač (alb. Durrës) je bil izjemna točka in zato že zelo zgodaj pomembna luka. A ostala je edina, kljub izborni legi ob Otrantskih vratih na prehodu med Jonskim in Jadranskim morjem. Močvirje so 'premagali' šele v obdobju socialistične Albanije po drugi svetovni vojni. Zaradi zaprtosti albanskega socialističnega režima je bila nizka obala kvečjemu učinkovita naravna ovira in nikakor ne odprto okno v svet. Nekoliko bolje so se odrezale črnomorske obale Bolgarije in Romunije. Tam so se oblikovala pomembna pristanišča Burgas in Varna v Bolgariji ter Constanța v Romuniji.

Na prvi pogled so omenjene države videti kompaktne, dejansko pa je taka ena sama. Edino Srbija ima glavno mesto in obenem najobsežnejše središčno območje približno v sredini državnega ozemlja tako, da je osrednji del tudi gosteje naseljen. Za vse ostale je značilna inverzna morfološka struktura, kjer so v osredju državnih ozemelj gorata območja. To posredno vpliva na razporeditev prebivalstva in oblikovanje večjih urbanih središč. Da to ni vedno nujno slabost, kaže primer gorate Avstrije, kjer se alpski lok vije sredi države, vsa velika mesta pa so izrazito na robu. Toda učinkovito razpredeno prometno omrežje in ustrezna prostorska politika je iz tega oblikovala občutno prednost Avstrije.

Takega primera na Balkanu ni. Bosna in Hercegovina je kljub kompaktnemu obrisu v osrednjem delu gorata in se je gospodarsko in prebivalstveno jedro moralo omejiti na razmeroma ozko Sarajevsko-zeniško kotlino. Podobno je v Makedoniji, kjer je 'strukturni' relief $\mathrm{z}$ menjavanjem tektonskih čokov in vmesnih kotlin ustvaril reliefno 'šahovnico' in s tem praktično pogojeval oblikovanje srednje velikih mestnih središč. Državno središče Skopje se je oblikovalo na severnem robu, kar je obenem (zaradi prebivalstvene strukture) tudi etnični rob. Prostorski domet prestolnice je spričo tega in slabo razvite prometne infrastrukture pač precej omejen. Črna gora je kot izrazito gorata država prometno odprta le na jugovzhodu, a še to proti izraziti albanski periferiji severne Albanije. Albanija ima gospodarsko in prebivalstveno težišče v ozkem podgorskem pasu; tam se je razvilo tudi glavno mesto Tirana. 
V zadnjem desetletju se pospešeno širi proti obali, medtem ko postajajo gorska območja vse bolj demografsko izpraznjena in gospodarsko shirana.

Bolgarija in Romunija prav tako kažeta obrise regionalne fragmentacije. Staro jedro Romunije v Vlaški nižini in Moldaviji je prvotno gravitiralo k Bukarešti. Ta je še danes primer uspešne in prepričljive prestolnice. Toda po osrednjem delu države se vije širok, visok, gozdnat in redko naseljen lok Karpatov. Pričakovali bi učinkovito regionalno središče sre-di Transilvanske kotline. Tega ni, morda tudi ne zaradi obstoja obsežnega madžarskega etničnega otoka, ki predstavlja največjo sklenjeno manjšinsko skupnost v Evropi. Na zahodu se Romunija na široko odpira proti Panonski kotlini. Na jugu tvori široka Donava z obsežnim pasom obrečnih močvirij in jezer sklenjen pas skoraj nenaseljenega sveta. To naravno pregrajo so doslej z mostovi premagali pri Ruseju proti Bolgariji in pri Đerdapu proti Srbiji. Podobno sliko nudi prostorska struktura Bolgarije, ki jo osrednji gorski hrbet Balkana (Stare planine) deli na severni in južni del. Južni del tvorita dve jedri: manjše območje Sofijske kotline z okolico, kjer leži državna prestolnica, ter obsežno Trakijsko nižavje ob srednjem toku reke Marice, ki je prometno dobro odprto proti obalam Egejskega in Črnega morja.

Nadvse zanimiv je primer Hrvaške. Kot izrazito podolgovata država izpostavlja nadpovprečen pomen obmejnih območij. Pri tem so osrednja območja države zaradi panonskih osamelcev mnogo redkeje naseljena kot robna, obmejna območja. Hrvaška regionalna središča (Varaždin, Virovitica, Osijek, Vukovar, Vinkovci, Slavonski Brod, Sisak in Karlovac) so položena na državni rob. Kljub bližini meje pa je makroregionalna lega Zagreba ugodna in predstavlja v danih razmerah zelo učinkovito prestolnico in središče države. Jadranski lok Hrvaške je razmeroma širok, saj ga povečujejo obsežna otočja v Dalmaciji s pripadajočim akvatorijem. Toda zaradi že prej omenjenih lastnosti površja je ta del redko naseljen, med izravnano obalno črto in notranjostjo pa je vrsta orografskih pregraj, kar prispeva k zoževanju obalne cone. Tudi potek jadranske avtoceste dokaj zvesto sledi bližini obale. Zato je maritimni značaj Hrvaške precej manjši, kakor bi pričakovali glede na dolžino obale in obseg akvatorija.

Poseben izziv pa je Kosovo, ki ga sestavljajo tri kotline: Kosovo, Metohija (alb. Dukagjin) in Malo Kosovo. Med prvima dvema je deloma zakraselo hribovje Drenica. Kosovsko-metohijski bazen obdajajo visoke gore z vseh strani. Na zahodu se strmo dvigujejo Prokletije, na jugu Šarsko gorstvo ter na severu Kopaonik. Proti Albaniji se pno nekoliko nižje, a zaradi izredne razčlenjenosti zelo težko prehodne albanske gore, ki jim ozka soteska Drima z veliko akumulacijo še povečuje ločevalni učinek. Edino na vzhodu so prehodi zaradi sredogorskega značaja pokrajine zložnejši. Kosovo je po dolinah odprto na sever (ibarska smer), jugu (vardarska smer) in vzhodu (moravska smer). Vse tri prometne smeri so prispevale, da je bilo Kosovo v preteklosti prometno naslonjeno na Srbijo, sedaj pa si pospešeno utira pot v smeri proti severnoalbanski obali. Zasuk v prometni strategiji tega prostora je rezultat ameriških in tudi turških interesov.

Že fizičnogeografski pregled kaže torej značilno mozaično podobo pokrajin, za katero je značilno izmenjevanje manjših gorskih pregraj in vmesnih kotlin. Velike nižine so na robu (Panonska in Vlaška), kotline v notranjosti polotoka pa večinoma skromnega obsega. Med morsko obalo in notranjostjo se dvigajo gorstva, ki predstavljajo učinkovite pregraje. Toda ključno podobo balkanskega pokrajinskega mozaika je prispeval zelo dinamičen zgodovin- 
ski razvoj, pri katerem izstopa dejstvo, da je bilo to območje med dvema ali tremi velikimi silami. Ta zgodovinsko pogojena robnost pa je pustila zanimivo kulturnozgodovinsko dediščino; njihov odraz so izredna narodna, jezikovna in verska pestrost ter obstoj številnih političnih entitet, katerih obseg in lega sta se v zadnjih dvesto letih naglo menjala. Tako se je že do neke mere naravno predisponirana mozaičnost balkanskih pokrajin še dodatno popestrila. Opisane spremembe državnih meja, menjavanje režimov in z njimi povezanih gospodarskih usmeritev so predispozicije razdrobljenosti še povečale. Ker so bile spremembe meja praviloma povezane s spopadi in so jim skoraj redno sledila tudi krajša obdobja gospodarskih kriz, je bil razvoj središčnih območij omejen in včasih celo povsem prekinjen. Vse to je prispevalo k širjenju perifernih območij. Vendar bi zadrževanje na tej temi zahtevalo preveč prostora, zato se glede na dostopne vire in literaturo osredotočamo na analizo sedanje prostorsko-socialne situacije in prek coniranja opredeljujemo centralna in periferna območja.

\subsection{Periferizacija periferije}

Druga izstopajoča značilnost Balkanskega polotoka je obseg perifernih območij. Središčna območja so razmeroma ozka in večidel omejena na državne prestolnice z najbližjim zaledjem, medtem ko so cone izrazitih periferij dokaj obsežne. Verjetno je takšno stanje v korelaciji z obsegom hribovitega in goratega sveta, ki ne dopušča niti razvoja velikih središč niti obsežnega zaledja mest. Periferna območja so tista, ki v državnem merilu izstopajo z negativnimi demografskimi tendencami, skromnejšo tehnično in družbeno infrastrukturo, nadpovprečno brezposelnostjo in na splošno slabimi gospodarskimi razmerami. Območje z značilnostmi periferije se naglo širi: periferizacija je torej napredujoč proces, ki veča medregionalne razlike, s tem pa posredno povečuje vzdrževalne stroške robnih pokrajin. Zametke periferizacije zasledimo že v osemdesetih letih 20. st., ko so se socialistične države soočile s hujšo krizo gospodarske strukture in globalne neuspešnosti. To je pripomoglo k hitremu zlomu socialističnih režimov, katerih ekonomska dediščina se je naglo sesula $\mathrm{v}$ slabo preglednih tranzicijskih procesih. Mnoga podjetja so propadla tudi zaradi načrtnega zniževanja vrednosti in omogočanja divjega lastninjenja. Toda novi 'turbokapitalisti' se pogosto niso najbolje znašli, kar je imelo drastične posledice: pričel se je množičen beg z robnih v središčna območja, še bolj pa v tujino. Na območjih s konflikti in vojnami je prišlo do velikih selitvenih premikov, kar je povzročilo nove primere krizne urbanizacije na eni in depopulacije na drugi strani. Po koncu lokalnih vojn in konfliktov so sledili selitveni tokovi zaradi boljših priložnosti in tudi mnogo bolj odprte zaposlovalne politike EU, vsaj v nekaterih državah. Trajna in začasna depopulacija žal perifernim območjem ni prinesla sprostitve npr. zemljiške posesti (odseljeni bi prodajali posest lokalnemu prebivalstvu in s tem sistematično povečevali velikost kmečkih obratov) in še manj inovacij. Na perifernih podeželskih območjih ostaja ostarelo, manj izobraženo in gospodarsko pasivno prebivalstvo, kulturna pokrajina pa propada.

K oblikovanju središčnih območij na Hrvaškem je najbolj pripomogla načrtna industrializacija po drugi svetovni vojni, po kateri se je oblikovalo pet industrijskih območij: zagrebška regija, vzhodna Slavonija z Osijekom, varaždinska, kvarnerska z Reko in srednje- 
dalmatinska s Splitom. Mesta in njihova gosteje naseljena zaledja tvorijo tudi središčna območja v tej podolgovati državi. Območje šibke koncentracije je tudi vzdolž obale. Sem se priseljuje prebivalstvo iz zaledja, računajoč na dohodke iz turizma. To je tudi območje pospešene gradbene dejavnosti, namenjene gradnji in vzdrževanju turističnih kapacitet, ki imajo izrazito sezonski značaj. Ozek obalni pas se vije od zahodne istrske obale prek severnega Kvarnerja, se nato skoraj prekine do Zadra, tam pa nadaljuje z nekaj prekinitvami proti jugu vse do Dubrovnika (Klemenčić 1993). Dubrovniku stisnjena lega med obalo in državno mejo z Bosno in Hercegovino očitno ne škoduje, saj je skoraj celoletno vezan na dotok obiskovalcev iz tujine. Tako deluje kot središče sredi obsežnih perifernih območij. Vendar so nekatera od središčnih območij dokaj omejena. Območje Varaždina in okolice je po nazadovanju tekstilne industrije v času tranzicije izgubilo precej gospodarske moči. Kmetijstvo je ostalo pomembna preživetvena panoga, sicer pa na malih razdrobljenih posestvih ne predstavlja gospodarskega izziva. Veliko slabše je v obsežnih območjih srednje in zahodne Slavonije.

Že pred osamosvojitvijo so se območja panonskih osamelcev demografsko praznila, potem pa je vojna (1992-95) privedla do prave demografske erozije. Celotna območja nekdanjih 'krajin', ki so nekaj let vztrajale kot paradržave, so po 'nevihti' (hrv. Oluja) avgusta 1995 doživele eksodus srbskega življa. Le redki so ostali in še redkejši so se vrnili. Mnogi so skušali iskati svojo poklicno priložnost bodisi na obali ali pa v mestih. Območja vzhodne in zahodne Slavonije, Korduna, Banije ter Kninske krajine so bila med spopadi precej poškodovana, infrastruktura in večina proizvodnih kapacitet uničena, prebivalci pa pregnani (Pirjevec 2003, 419-420). Večino teh območij je bila depopulacijskih že pred vojno (Veliki geografski atlas Jugoslavije 1987, 42-45), tako da se je zaradi spopadov in političnih sprememb ta proces le še dramatično pospešil. Za nameček se je glavnina novejših prometnic, še posebej pa jadranska avtocesta, izognila kriznim območjem. Verjetno so k temu prispevale tudi nejasne pravno-posestne razmere. Poleg tega je za potrebe turizma obalna avtocesta prikladnejša od zaledne različice. Marsikje so še opazne sledi vojaškega delovanja, od ruševin do prisotnosti minsko-eksplozivnih sredstev, ki predstavljajo precejšnjo varnostno in posledično tudi gospodarsko grožnjo. Problem teh območij je sedaj prvenstveno demografska izčrpanost, zaradi katere je kulturna pokrajina že pričela propadati. Ker so to hkrati obmejna območja, predstavljajo na Hrvaškem obsežen 'mehki trebuh' države. Le okoliščini, da na drugi strani meje (v Bosni in Hercegovini) ni veliko bolje, gre pripisati, da se te poteze ne kažejo še bolj negativno.

Drugo veliko demografsko izpraznjeno območje na Hrvaškem pa je večina otokov. Vendar v poletni turistični sezoni ne dajejo takega vtisa, saj je množica turistov in tudi hrvaških državljanov, ki v hladni polovici leta živijo v mestih oziroma na obali, daje vtis živahne, obljudene in gospodarsko dinamične pokrajine (Nejašmić 2006, 148-150).

Bosna in Hercegovina je doživela zaradi državljanske vojne in lokalnih medetničnih spopadov, ki jih nekaterih slikovito, a vendar dovolj jasno opisujejo kot 'vojno vseh proti vsem' (Calic 1996, 89-96), zelo močno povečanje perifernih območij. Medtem ko je razmeroma soliden naravni prirastek še v osemdesetih letih 20. st. zagotavljal stabilno poselitev, je v devetdesetih letih zaradi političnih okoliščin prišlo do velikih notranjih selitev. Po nekaterih ocenah je bivališče zamenjala polovica bosanskega prebivalstva (Calic 1996, 268-270), poleg 
žrtev in stalno odseljenih, ki pomenijo za državo pač demografsko izgubo. Pisan bosanski verski in narodni mozaik se je v marsičem poenostavil; prišlo je do bistveno večje etnične homogenizacije na lokalnih ravneh (Toal in Dahlman 2006, 349-366). Obsežna območja so izgubila tudi več kot polovico prebivalstva.

Tako se država danes otepa z obsežnimi 'praznimi’ območji, ki se razprostirajo v hribovitih predelih severovzhodne Bosne, vzhodne (kraške) Hercegovine, marsikje v osrednji (danes srbski) Bosni ter še posebej na zahodu. Na drugi strani so nekatera mestna območja doživela nesluteno koncentracijo kot rezultat begunstva, ki se je po vojni spremenilo v stalno naseljenost. Mesta kot so Banja Luka, Tuzla, Bihać in Sarajevo so se precej povečala. Tuzla se je npr. praktično podvojila (Nurković in Mirić 2006, 423-429). Poseben primer predstavlja distrikt Brčko, edino ozemlje dvojne federacije, ki je neposredno pod oblastjo zvezne (bosanske) vlade in je gospodarsko oživelo zaradi davčnih ugodnosti. Poslovne priložnosti so ob ugodni legi blizu savskega prometnega koridorja oblikovale v marsičem novo jedro goste poselitve in živahnih poslovnih aktivnosti (Nurković 2006, 134-141).

Črna gora in Srbija sicer nista doživeli neposrednih vojaških spopadov na lastnih tleh, a so bili mnogi prebivalci udeleženi v spopadih. Predvsem pa so zlasti gospodarske, socialne in socialno-psihološke posledice opazne tudi tukaj, poleg reke beguncev, ki se je s Kosova, iz Bosne in Hercegovine ter Hrvaške zgrinjala proti osrednjemu delu Srbije. Pričakovanja, da bi z begunci nadomestili skoraj prazna območje vzhodne Srbije, so se hitro izkazala za popolno iluzijo. Večinoma so se naselili prav na robu Beograda in Novega Sada, pričakujoč več možnosti za delo (Kicošev 2006).

Poseben primer so nekateri begunci s Kosova, saj živijo deloma v okvirih srbskih enklav na Kosovu, deloma pa v Beogradu. Preostali kosovski Srbi jih imenujejo 'vikendaši'‘ . V Srbiji kažeta edino Beograd in Novi sad značilne poteze koncentracije in sicer tako v demografskem kakor (še bolj izrazito) gospodarskem pogledu (Statistical Office of the Republic of Serbia 2009). Kljub vojnam in gospodarski osami je srbska prestolnica prepričljivo središče, čeprav je izgubila veliko svojega nekdanjega jugoslovanskega zaledja. Toda urbani vpliv Beograda zaradi dosedanje pretežno centralistične prostorske politike ne seže prav daleč na podeželje. Že 40 km oddaljeno Smederevo je po krizi železarske industrije doživelo izrazito nazadovanje. Medregionalne razlike se opazno povečujejo. Obsežni predeli vzhodne in jugozahodne Srbije so že v sedemdesetih letih 20. st. izkazovali izrazito demografsko nazadovanje, ki je bilo odsev zelo skromnih gospodarskih možnosti. Indeks staranja je bil v karpatskem delu Srbije najvišji v Jugoslaviji (Veliki geografski atlas Jugoslavije 1987, 46-47). Pravih regionalnih središč ni bilo. Zapiranje nekoč donosnih rudnikov (Bor, Majdanpek) in zaton barvne metalurgije sta proces periferizacije še okrepila. Periferizacija robnih delov države je resen problem, saj predstavlja to območje skupaj z južnimi (z albanskim prebivalstvom) in jugozahodnimi deli (z bošnjaškim prebivalstvom) izrazit 'mehki trebuh' Srbije. Posebno območje je Sandžak. Tako v Srbiji kot v Črni gori ga naseljuje muslimansko prebivalstvo, ki se večidel, a ne povsem dosledno, opredeljuje kot Bošnjaki. Zelo močna je tudi regionalna pripadnost (Sandžačani). Nekateri analitiki so pričakovali, da se bo cona spopadov razširili tudi v ta predel, vendar je - presenetljivo - območje ostalo dokaj mirno.

6 Navedbe, pridobljene na terenskih vajah iz politične geografije maja 2007 na Kosovu in v Albaniji. 
V Črni gori doživljata zmerno koncentracijo le območje Podgorice in bližnjega sosedstva ter ozek pas na obali. Tam je zaznavna izredna gradbena aktivnost, kar je treba pripisati predvsem razvoju turizma in lastniškim spremembam, manj pa doseljevanju. Obalni predeli so selitveno razmeroma pasivni (Zavod za statistiku Republike Crne gore 2009). To so tudi edina območja z lastnostmi vsaj gospodarske koncentracije. Sicer pa je drugod v tej gorati državi mogoče opaziti negativne demografske in gospodarske težnje, nedvomno tudi zaradi vpliva demografsko izpraznjenega sosedstva (v Hercegovini in Bosni) ter nemirnega območja Kosova na vzhodu.

Zelo zanimiv je primer Kosova. Zaradi ohranjanja visoke rodnosti ga tudi sorazmerno intenzivno razseljevanje vsa desetletja po drugi svetovni vojni ni posebej prizadelo. Nasprotno, prebivalstvo je stalno naraščalo, gospodarska in socialna sestava pa temu ni bila prilagojena. Industrializacija ni bila uspešna, kljub sorazmerno velikim vlaganjem. Kosovo je dolgo zadrževalo svoj agrarni in podeželski značaj, tradicionalni življenjski stili pa so se ohranjali tudi v urbanih pogojih življenja. Kosovo je bilo po eni strani investicijska vreča brez dna, po drugi pa praktično kolonija, ki je zadrževala svoj periferni značaj in gospodarsko ter politično odvisnost (Hofbauer 2008, 73-75). Zaostrovanje medetničnih odnosov, ki ima-jo večstoletne korenine, je še zmanjševalo možnosti gospodarske preobrazbe. Upor leta 1981 in odprti konflikti so vzpostavljali elemente vzporedne 'sive' ekonomije. Podeželje je predstavljalo zatočišče in kmetijstvo pomemben del preživetvene strategije zlasti albanskega prebivalstva.

Do odločilne in nagle prostorske in družbene preobrazbe je prišlo zaradi političnih procesov. Albanska vstaja leta 1998, ki ji je sledila srbska ofenziva in tej val množičnega begunstva, pa je stvari močno spremenil. Napad zveze NATO je Kosovo praktično iztrgal Srbiji in ga postavil pod mednarodni nadzor. Begunci so se vrnili na robove mest, ki so se v kratkem času močno povečala. Ta kaotična, zasilna 'krizna' (ali tudi 'turbo-') urbanizacija je posegala predvsem po nekdanjih državnih zemljiščih (območja nekdanjih agrokombinatov) ter po zemljiščih Srbov, ki so se podali v begunstvo proti Srbiji (predvsem proti Beogradu) ter v notranji eksil v prostorsko omejene enklave. Zaradi nenačrtnosti in odločno preskromne infrastrukturne podpore se že sedaj tvorijo nova jedra lokalnih konfliktov (Vöckler 2008). Tako so se pod nadzorom mednarodnih sil KFOR, ki so skušale z misijo UNMIK postopoma oblikovati stabilne razmere, ustvarjale povsem nove družbene in prostorske prilike, ki so verjetno trajno zaznamovale osrednji del Kosova. Divje prilaščanje nepremičnin, gradnja na robu mestnega obroča ter vzdolž prometnic je statistično in dejansko sprožilo naglo urbanizacijo. Storitveni sektor je postal vodilni, še posebej, če k temu prištevamo dobršno mero sive ekonomije, ki je slej ko prej vsa v storitvenih dejavnostih. Tako je prišlo do izrazite centralizacije v osrednjih delih, medtem ko so se gorska in hribovita območja (npr. v Drenici) že pričela prazniti. Priština je dosegla v nekaj letih praktično podvojitev prebivalstva (blizu pol milijona), intenzivno pa so naselili tudi ravninske del Kosovega polja vzdolž prometnic in ob načrtovani smeri avtoceste od Prištine proti Tirani in Draču. Te prostorske spremembe so, če upoštevamo značilnosti prostorskega razvoja kriznih območij, pričakovane in logične, a dolgoročno precej problematične. Kakor kažejo načrti kosovskih oblasti, so nastalo situacijo dejansko vzeli kot izhodišče in nanjo naslanjajo bodočo strategijo prostorskega razvoja (Dokumente të prodhuara 2003-2006). Žal se s tem odrekajo ne le predragocenim vodnimi 
virom (Kosovo polje je najpomembnejši kosovski vodonosnik), ležiščem lignita, ki so plitvo pod površjem in v osrednjem delu dostopni v obsežnem dnevnem kopu, ter nepovratno krčijo dobre kmetijske površine, kar se pri najbolj naseljeni (agrarno odločno prenaseljeni!) balkanski državi lahko hitro maščuje.

Povečanje razlik med prištinsko-kosovsko krizno aglomeracijo (in s tem središčnim območjem) ter vse bolj izpraznjujočo se Drenico (periferijo) odpira boleče dileme prostorskega in gospodarskega razvoja ter okoljskih zadreg. V tej luči se utegne kriza poglabljati zaradi nezadostnih (dejansko pa nesmotrno rabljenih) življenjskih virov in lokalnih prostorskih konfliktov. Mednarodne sile so tu dodatni prostorski dejavnik, saj so zaradi taktičnih potreb zasedle strateško najpomembnejše cone. Tako je nemška baza na prometno zelo dobro dostopnem robu Prizrena, italijanska na obsežnem vodonosnem vršaju pri Peći, ameriška baza Bondsteel pa blizu prometnega križišča med ibarsko in moravsko prometno smerjo - toda obenem tudi v povirnem delu Nerodimke in Sazlije (območje je znano tudi po viličenju bifurkaciji). $^{7}$

Območje Makedonije kaže nekaj posebnosti. Prepričljivo državno središče in s tem (pravzaprav edino) središčno območje države predstavlja skopska aglomeracija, ki pa je zaradi gorate soseščine in etničnega roba dokaj omejena. Nagla urbanizacija je že v preteklosti precej izčrpala hribovita podeželska območja in oblikovala (podobno kakor v Srbiji) skoraj prazna območja v obsežnih predelih vzhodne in južne Makedonije. Veliko ljudi je bilo na začasnem delu v tujini. Napete situacije v širšem sosedstvu, zlasti pa na Kosovu, so ovirale razvoj domačega zasebnega podjetništva in povzročile tudi gospodarsko erozijo obsežnih podeželskih območij. Tako se le ozka območja, pravzaprav točke, ki jih predstavljajo regionalna središča v posameznih kotlinah (npr. Bitola in Prilep v Pelagoniji, Strumica na jugovzhodu, Kavadarci v Tikvešu, Ohrid na zahodu), izkazujejo kot šibka središča. Nekatera večja regionalna središča (npr. Štip in Kočani) izkazujejo gospodarsko in demografsko nazadovanje; torej precej izrazite poteze perifernosti (Državen zavod za statistika Republike Makedonije 2009). Območja periferije se povečujejo (Madjevik 2006).

Podobno kakor Kosovo je tudi Albanija doživela korenit zasuk v prostorski strukturi ozemlja. Medtem ko so v socialističnem obdobju skrbeli za poselitev celotnega ozemlja in spodbujali gospodarske dejavnosti tudi na izrazito neugodnih območjih, so po padcu socialističnega režima sledile velike spremembe. Velik eksodus prebivalstva v devetdesetih letih (med leti 1996-97 se je po ocenah odselilo okrog 700.000 prebivalcev; med temi so verjetno všteti tudi nekateri prebivalci Kosova; Fischer Weltalmanach 1999, 36) je neposredno in pozneje tudi posredno oblikoval vse obsežnejše območje praznjenja v goratih predelih. Čeprav gospodarske razmere v državi še niso posebej ugodne, doživljata območji Tirane in Drača radikalne spremembe, torej izrazito centralizacijo, vsa ostala območja pa z izjemo posameznih točk (večja regionalna središča kot so Skader, Valona, Elbasan in Korča) pa ostajajo skromne središčne točke sredi vse bolj obsežne periferije (Atlas i Shqipërisë 2003, 68-71). Tirana je število prebivalstva skoraj podvojila in ima sedaj po uradnih podatkih okrog 350.000 prebivalcev (Fischer Weltalmanach 2009, 17), po ocenah pa okrog pol milijona prebivalcev. Določeni gorati predeli so že izgubili večji del prebivalstva do te mere, da

7 Informacije, pridobljene na terenskih vajah iz politične geografije maja 2007 na na Kosovu. 
emigracijskega potenciala skorajda ni več (Atlas i Shqipërisë 2003, 72). Zaloge emigrantov naj bi bile nekoliko večje na jugu, verjetno zaradi možnosti legalnih in ilegalnih čezmejnih delovnih migracij v Grčijo. Osrednji del, ki ga predstavlja predvsem ozek pas ozemlja med Tirano in morsko obalo pri Draču, se tako izrazito polni, ostali deli pa prebivalstvo izgubljajo.

Grčija se kot izrazito pomorska država sooča s problemi depopulacije zlasti na manjših otokih, ki, podobno kot na Hrvaškem, živijo poleti v živahnem turističnem utripu, pozimi pa potonejo v precejšnje mrtvilo. Grčija je že praktično vseskozi močno navezana na morje, kar se kaže tudi v bistveno večji gostoti poselitve v ozkem obalnem pasu, medtem ko je zlasti v notranjosti Epira, Makedonije in grškega dela Trakije mogoče slediti značilnim pojavom perifernosti (General Secretariat of the National Statistical Service of the Greece 2009 census 2001).

Osrednje središčno območje predstavljajo prostorsko razmeroma ozki predeli Atike in Evbeje z atensko aglomeracijo, ki z več kot 3 mil. prebivalcev predstavlja (razen Carigrada) prepričljivo največjo urbano koncentracijo v tem delu Evrope. Drugo jedro je pri Solunu. Široka ravnica ob spodnjem Vardarju (Solunsko polje) daje mestu ob izteku moravskovardarske prometne smeri odlično izhodišče, ki pa zaradi precej slabih odnosov s sosedami v preteklosti ni imelo vidnejše vloge. Prav tako mu je škodovala faza razpada Jugoslavije in niza lokalnih vojn. Za gospodarski razvoj severne Grčije sta mirovni proces in revitalizacija kriznih območij osrčja Balkana vitalnega pomena (Kostopoulou 1996, 153).

V Bolgariji je Sofijska kotlina z glavnim mestom prepričljivo nacionalno središče ob pomembni prometnici iz Podonavja po moravski prometni smeri proti Carigradu in Mali Aziji. Ozka kotlina in gorato zaledje mesta zmanjšujejo urbani pomen in gravitacijski vpliv Sofije. Vendar robno položena prestolnica po številu in gospodarski moči daleč prekaša ostala bolgarska mesta. Drugo največje mesto Plovdiv leži v obširnem in odprtem Trakijskem nižavju ob reki Marici in tvori z bližnjimi srednje velikimi mesti širšo aglomeracijo. Tretje jedro je na črnomorski obali: Varna in Burgas (Benkovič Krašovec 2003). S projekcijami novih plinovodnih omrežij (Južni tok) pomen obeh pristanišč narašča.

Severna Bolgarija (bolgarsko Podonavje) je demografsko precej nazadovala, še posebej v severovzhodnem delu. Kmetijstvo, ki je bilo nekoč organizirano v obliki državnih posestev in kolektivnih zadrug (podobno sovjetskim kolhozom), je z menjavo družbenega reda propadlo, privatizacija pa je le deloma obnovila nekdanje proizvodne kapacitete. Tako je večji del severne Bolgarije gospodarsko in demografsko nazadoval (Totev, 2001, 318324). V osemdesetih letih 20 . st. so takratne socialistične oblasti celo načrtno pospeševale odseljevanje, še posebej na območjih, kjer so bile naseljene manjšine. Odselilo se je precej Turkov iz območja Deli Orman na severovzhodu, medtem ko je Strandža, pokrajina ob meji s Turčijo, precej opustela (Dimitrov 1995, 174-199). Strandža je tako kljub ugodnim razmeram za kmetijstvo izpraznjena pokrajina. Na turški strani je slika povsem drugačna, saj na to območje močno vpliva velikanska carigrajska mestna aglomeracija. Prav tako demografsko in gospodarsko osiromašeno je območje Rodopov, ki ga naseljujejo Pomaki in bolj na vzhodu razmeroma številčna turška manjšina.

Jug Bolgarije je - podobno kot območje nekdanjih 'krajin' na Hrvaškem in predeli vzhodne Srbije - iz strateškega vidika ranljivi 'mehki trebuh' države. To je še toliko bolj poudarjeno, 
ker je konkurenčno območje na drugi strani meje (turška Trakija) gosto naseljeno in demografsko vitalno, gotovo tudi zaradi bližine carigrajske aglomeracije. Bolgarija je tudi država z eno najnižjih stopenj rodnosti na svetu: le okrog 9 promilov in zmerno smrtnost (15 promilov) (National Statistical Institute of Republic of Bulgaria - census 2001).

Romunija je v fazi tranzicije doživela korenite prebivalstvene in zato tudi prostorske spremembe. Čeprav je v splošnem slediti predvsem negativnim demografskim trendom (Statistical Yearbook 2007), ki jih povzroča zelo nizka rodnost in začasno ter trajno odseljevanje, so se nekatera območja po zaslugi izdatnih tujih investicij precej opomogla in je mogoče govoriti o revitalizaciji (Rizopoulos 2003, 89-91). Sprostitev čezmejnih odnosov je pozitivno vplivala zlasti na zahodu ob meji z Madžarsko, kjer je čezmejno sodelovanje zdaleč najbolj učinkovito (Ilies 2004). Oblikovala so se tri glavna jedrna središčna območja: Bukarešta (po dosegljivih podatkih velja nekako za tretje največje gradbišče združene Evrope, torej za Berlinom in Varšavo, kar je skoraj nesporno zasluga vstopa države v EU). Kot središče velike države, in tudi oddaljenost konkurenčnih središč, postavlja Bukarešto za pomembno evropsko makroregionalno središče, ki sega do industrijsko-rudarskega območja v Munteniji ter proti delti Donave (Galați in Brăila) ter prek Cernavode in Donave na Constanţo.

Drugo in tretje jedro sta bistveno šibkejši: prvega predstavlja romunski Banat s Temišvarom, kjer so na podlagi uspešnega umeščanja industrije (zlasti selitev italijanskih podjetij tekstilne in usnjarske ter nemške strojne in kovinske industrije) uspešno premagali tranzicijske težave. Drugo središčno območje je Cluj-Napoca, ki dobiva nov pomen in vrsto priložnosti šele s širjenjem evropskih transkontinentalnih prometnic. V Romuniji kažejo najbolj periferne poteze regije Maramureş na severu, skoraj celotna Moldavija in Oltenija na jugozahodu, torej območja na severu in vzhodu države, ob meji z Ukrajino (Erdeli, 2000 70-73).

Ob prebivalstvenih spremembah je treba opozoriti še na problem zaposlovanja v tujini, ki je bil ponekod (Grčija, nekdanja Jugoslavija) močno uveljavljen že od šestdesetih let 20. st. dalje. Albanija je doživela pravi eksodus sredi devetdesetih let, v Bolgariji in Romuniji pa se je takrat pričel močan tok legalnih in ilegalnih zaposlovanj v Italiji, Franciji in Španiji ter se je z vključitvijo obeh držav v EU še stopnjeval. Gre za več milijonov ljudi, zlasti mladih, zato se to $\mathrm{v}$ teh državah krepko pozna tudi pri značilnostih demografskih gibanj. Zaposlovanje $\mathrm{v}$ tujini je značilno tudi za večino držav naslednic nekdanje Jugoslavije, še posebej za Bosno in Hercegovino in Srbijo. Čeprav sta obe nekdanji republiki doživljali zelo različen politični razvoj in zgodovinsko usodo, so demografske tendence presenetljivo sorodne.

\subsection{Narodna sestava prebivalstva}

Posebno pozornost namenjamo tudi značilnosti narodne (jezikovne, kulturne) in verske sestave prebivalstva. Narodna pripadnost ima izjemno družbeno moč, ki so jo domače elite, še bolj pa evropska diplomacija kljub dovolj razpoznavnim indikatorjem, da se zaostreni odnosi bližajo konfliktom, očitno podcenjevale. Tudi v fazi reševanja kriz so vsako krizno žarišče reševali ne le posebej, temveč tudi na povsem svojski način. Čeprav si smemo dovoliti misel, da so raznolike razmere in širši mednarodni značaj dopuščali ali celo vzpodbujali taktično prilagajanje okoliščinam, pa po drugi strani ne gre spregledati dejstva, da dolgoročne 
evropske vizije za nemirni Balkan pač preprosto ni bilo. Pomanjkanje geopolitike pa se - kot kaže - očitno nadaljuje (Rogelj 2006), zato bo verjetno na poti integracije držav 'Zahodnega Balkana' pač treba pričakovati še nekaj napak. Še bolj zmotno pa je predpostavljati, da bo lahko okvir združene in ekonomsko uspešne EU prekril ali celo odpravil razpoke med narodi in državami, ki se še sedaj soočajo z resnimi posledicami nedavnih lokalnih vojn.

Konfliktni potencial izvira prav iz zapletenih medetničnih razmerij med državami in znotraj njih. Prikrite agresivne ideologije so dejstvo, ki ga ne bi smeli prezreti. Te pa niso, kakor ugotavlja Seewan (1993, 3-8), lastne le nemirnejšemu srednjemu in vzhodnemu delu Evrope (in torej vsaj deloma posledica totalitarnih režimov), temveč se s kalmi nacionalističnih gibanj in desno-ekstremnimi pojavi srečujejo tudi v utrjenih demokracijah zahodne Evrope. V tej luči se zdijo načelna izhodišča, ki jih dokaj blagohotno pošiljata v eter Svet Evrope in Evropski parlament, zgolj izražena želja, nikakor pa ne načrt ali vsaj želeni standard evropskih držav. Zato je kazanje s prstom na pregovorno konfliktni Balkan le odmik od realnosti in pravzaprav nadaljevanje pokroviteljskega odnosa do 'vmesne Evrope', ki je bila 'pas črepinj' ves čas vzpona evropskih nacionalizmov in imperializmov od srede 19. st. dalje. Kajti dejstvo je, da je balkanski prostor dejansko še vedno poligon, na katerem so ključni igralci v varnem strateškem zaledju zunaj regije. Tehtno je torej vprašanje, kdaj in v kolikšni meri je mogoče prakse in teorije sožitja raznorodnih družb iz Srednje in Zahodne Evrope prenesti v prakso malih, a etnično heterogenih (torej multietničnih) okolij Balkana.

Toda večina narodov Balkanskega polotoka ima v svoji moderni zgodovini (ki je obenem čas oblikovanja narodov kot relativno trajnih družbenih agregatov in tudi nacionalnih držav) izkušnjo bivanja v mnogonarodnih političnih tvorbah. Otomanski, habsburški in ruski (sovjetski) imperij so se zlomili prav na področju upravljanja z etnično raznolikostjo. Na njihovih pogoriščih so nastale nove 'nacionalne' države, ki naj bi pomenile uresničitev nacionalnih ideologij. Toda skoraj vse po vrsti so bile v resnici etnično heterogene. Jugoslovanska izkušnja je zanimiva, saj je že v začetku negirala Črnogorce kot narod in državo, reducirala pa tudi avtonomistične težnje Hrvatov in Slovencev.

Jugoslovanska ideja je tako hitro postala vzvod velikosrbskega nacionalizma, zato je tudi rodila odpor, ki je dosegel vrh med drugo svetovno vojno. Krvava izkušnja nepreglednega medetničnega spopadanja je bila popotnica za urejanje odnosov med državotvornimi narodi. Ti so dobili svoje republike, manjšin pa so se skušali znebiti. Pri nemški je to uspelo skoraj v celoti (Janko 1983; Biber 1966), pri italijanski večinoma (Klemenčič in Zupančič 2004, 853896), medtem ko pri madžarski skupnosti zaradi razvoja dogodkov tako na Madžarskem kakor v Jugoslaviji načrtovane selitve niso uspele (Kocsis in Kocsis-Hodosi 1998).

Jugoslovanska država je po drugi svetovni vojni torej zadržala zunanji okvir, temeljito pa je spremenila notranjepolitični zemljevid. Rekonstrukcija Jugoslavije in zagotavljanje njenih večnarodnih temeljev je začasno zadostilo potrebam nacionalizmov udeleženih narodov. Oblikovale so se tudi meje republik in avtonomnih pokrajin, s podmeno, da so medrepubliške meje pač notranja jugoslovanska zadeva in imajo pač zgolj administrativni značaj. Temu seveda ni bilo tako, saj so imele republike dokaj široko avtonomijo in so na svojem ozemlju oblikovale nacionalne institucije ter vodile 'nacionalno' politiko. S tem so torej republike krepile svojo avtonomijo, realno upravljale z ozemljem in dejansko uresničevale svojo državnost. Te meje so vsekakor bile politične! 
Ko je sledil razpad jugoslovanske federacije, so se oglasile težnje po rekonstrukciji meja, očitno pač v težnji, da se pripadniki enega naroda združijo v eni državi. Soočeni sta bili dve povsem legitimni, toda v praksi pogosto nasprotujoči si načeli: o samoodločbi narodov in o ozemeljski integriteti. Tehtanje obeh načel se je drastično pokazalo pri burnih razpravah ob osamosvojitvi Kosova, ki so ga mnoge evropske države, računajoč na možnost, da se utegnejo avtonomaške težnje uresničiti v politični secesiji, taktično odklonile. Pri primeru Kosova so torej prevladale opcije, ki so bile bolj naklonjene samoodločbi narodov. Primer Bosne in Hercegovine ima drugačno izhodišče, saj so tvorci bosanske politične arhitekture izhajali iz načela ozemeljske nedotakljivosti. Ta politični aksiom je dokončno dobil domovinsko pravico s Konferenco o varnosti in sodelovanju v Evropi (Helsinki 1974); iz tega se je pozneje razvila Organizacija za varnost in sodelovanje v Evropi (OVSE). Bolj kot načelo je tu očitno igrala vlogo njegova pragmatičnost.

Vprašanje je torej le, kako v podrobnostih interpretirati pojem 'politične meje'. V ta kontekst po svoje sodijo tudi polemike o morskih mejah in korekcijah poteka mejne črte na kopnem, ki pa dopuščajo določeno taktično prilagajanje. Meje so dejansko 'žive', spreminjajoče se. Celovitejšo rešitev mejnih sporov, urejanja manjšinskih vprašanj in s tem tudi ureditev bilateralnih odnosov bi verjetno dosegli, če bi izhajali iz nasledstvenega svežnja bivše jugoslovanske federacije, vključno s podedovanjem mednarodnih in bilateralnih dosežkov Jugoslavije. Vendar so med evropskimi državami glede tega odločno prevladale parcialne težnje. V duhu evropskega partikularizma deluje EU do Balkana tudi še danes in razgalja pokroviteljski odnos do celotne balkanske regije in krepak primanjkljaj operativne geopolitike do območij, ki jih šteje za 'evropska'.

Toda vrnimo se k pregledu etnične in verske podobe preučevanih držav, kjer lahko izpostavimo tri ključne značilnosti:

- večina držav je etnično razmeroma heterogenih;

- do etnične homogenizacije je ponekod prišlo na regionalni in lokalni ravni;

- veliko je pojavov, ko so pripadniki enega naroda (ali jezikovne skupine) organizirani v dveh politično-teritorialnih enotah.

Pri pregledu narodne (etnične) strukture prebivalstva je vendarle potrebno nekaj kratkih pojasnil. Gre za področje, ki ga statistično ponekod beležijo, drugod ne. Poleg različnih kriterijev je treba upoštevati tudi družbeno klimo, še posebej odnos do manjšin, ki lahko statistično pomembno znižujejo število in delež manjšinskega prebivalstva. Nekaterih skupin prebivalstva niti ne prepoznavajo kot 'drugačne'. Težavo pri tem imajo posebej Makedonci, saj so v Grčiji le prebivalci grške pokrajine Makedonije, v Bolgariji so to Bolgari, Albanija po narodni pripadnosti ne popisuje in se statistično kaže kot zelo homogena. Muslimanski prebivalci Sandžaka (t.i. Sandžaklije) se večinoma opredeljujejo kot 'Bošnjaki', vsi pa zanesljivo ne, saj ima opredelitev tudi regionalni prizvok; tej skupini naj bi pripadali predvsem muslimani v Bosni in Hercegovini, ki so se po jugoslovanskih statistikah uradno šteli za 'Muslimane v pomenu narodnosti'.

Podobno težavo imajo tudi etnične skupnosti, ki nimajo nikjer 'svoje' teritorialne enote z vsaj omejeno avtonomijo. Najštevilčnejši so brez dvoma Romi, čeprav jih statistike zajamejo le deloma in je njihovo število močno podcenjeno. Poleg tega se nekatere skupine Romov 
Preglednica 1: Pregled narodne sestave prebivalstva držav na Balkanskem polotoku (v tisočih) Table 1: Ethnic composition of nation-states on the Balkans (in thousands)

\begin{tabular}{|c|c|c|c|c|c|}
\hline Država & $\begin{array}{l}\text { Število } \\
\text { prebivalcev } \\
\text { (skupaj) }\end{array}$ & $\begin{array}{c}\text { Število in delež } \\
\text { pripadnikov } \\
\text { titularnega naroda } \\
\text { v državi }\end{array}$ & $\begin{array}{c}\text { Skupno } \\
\text { število } \\
\text { pripadnikov } \\
\text { titularnega } \\
\text { naroda, ne } \\
\text { glede na } \\
\text { državo (1) }\end{array}$ & $\begin{array}{c}\text { Število in delež } \\
\text { drugih etničnih } \\
\text { skupnosti v državi } \\
\text { (2) }\end{array}$ & $\begin{array}{c}\text { Število in delež } \\
\text { pripadnikov } \\
\text { titularnega } \\
\text { naroda v } \\
\text { sosednjih } \\
\text { državah (1) }\end{array}$ \\
\hline Hrvaška (3) & 4437 & $3977(89,6 \%)$ & 4700 & $\begin{array}{l}\text { Srbi } 202(4,5 \%) \text {, } \\
\text { ostali } 258(5,9 \%)\end{array}$ & $700(15 \%)$ \\
\hline $\begin{array}{l}\text { Bosna in } \\
\text { Hercegovina } \\
\text { (4) }\end{array}$ & 3926 & $\begin{array}{c}1885 \text { (48 \%), Srbi } \\
1453(37 \%), \text { Hrvati } \\
550(14 \%)(5)\end{array}$ & 2170 & ostali $40(1 \%)(5)$ & $\begin{array}{c}\text { (Bošnjaki) } 285 \\
(13 \%)\end{array}$ \\
\hline Srbija (5) & 7498 & $6201(82,7 \%)$ & 8300 & $\begin{array}{c}\text { Madžari } 292(3,9 \%) \text {, } \\
\text { Bošnjaki } 135(1,8 \%) \text {, } \\
\text { ostali } 870(6,5 \%)\end{array}$ & $2100(25 \%)$ \\
\hline Črna gora (6) & 620 & $268(43,2 \%)$ & 320 & Srbi $198(32 \%)$ & $50(15 \%)$ \\
\hline Kosovo & 2127 & $1957(92,0 \%)$ & (gl. Albanija) & $\begin{array}{l}\text { Srbi } 113(5,3 \%) \text {, } \\
\text { Turki } 57(2,7 \%)\end{array}$ & (gl. Albanija) \\
\hline Makedonija & 2022 & $1298(64,2 \%)$ & 1560 & $\begin{array}{c}\text { Albanci } 510(25,2 \%) \text {, } \\
\text { Turki } 79(3,9 \%), \\
\text { Srbi } 36(1,8 \%), \\
\text { ostali } 99(4,9 \%)\end{array}$ & $250(15,0 \%)$ \\
\hline Albanija & 3172 & $3040(95 \%)$ & 5650 & ostali $132(5,0 \%)$ & $2610(46,2 \%)$ \\
\hline Grčija (2) & 11.147 & $10.868(97,5 \%)$ & 11.700 & ostali $280(2,5 \%)$ & $832(7,1 \%)$ \\
\hline Bolgarija (2) & 7694 & $6425(83,5 \%)(7)$ & 6800 & $\begin{array}{l}\text { Turki } 732(9,5 \%) \text {, } \\
\text { Romi } 355(4,6 \%) \text {, } \\
\text { ostali } 185(2,4 \%)\end{array}$ & $370(5,5 \%)$ \\
\hline Romunija (2) & 21.590 & $19.323(89,5 \%)$ & 22.500 & $\begin{array}{c}\text { Madžari } 14256,6 \%) \text {, } \\
\text { Romi } 550(2,5 \%) \text {, } \\
\text { Nemci } 65(0,3 \%) \text {, } \\
\text { ostali } 240(1,1 \%)\end{array}$ & $2250(10 \%)$ \\
\hline
\end{tabular}

Viri/Sources - Opombe/Remarks:

(1) preračunano iz različnih virov ter ocen;

(2) navedbe po Fischer Weltalmanch 2009; preračunano;

(3) Republika Hrvatska - Državni zavod za statistiku. Popis stanovništva 2001 (tabela 12: Stanovništvo prema narodnosti, po gradovima/opčinama);

(4) Federalni zavod za statistiku Federacije Bosne i Hercegovine. Stanovništvo prema izjašnjenju o nacionalnoj pripadnosti po opštinama 1991; v nadaljevanju so uporabljene ocene po Fischer Weltalmanch 2009;

(5) ocene za 2006 po Fischer Weltalmanch 2009;

(6) Zavod za statistiku Republike Crne gore;

(7) enako navaja tudi National Statistical Institute of Republic of Bulgaria 2007 
opredeljujejo posebej; npr. t.i. Egipčani v Makedoniji. Vlahov je po nekaterih navedbah v Srbiji in v Romuniji veliko več kot pa po statističnih popisih. Nekateri avtorji združujejo Gorane, Torbeše in Pomakev eno skupino, čeprav razen nekaj podobnosti nimajo nič skupnega. Če upoštevamo jezikovne razmere, je to v nekaterih primerih lahko zelo problematično. Realno so bile razlike med hrvaškim, bosanskim, črnogorskim in srbskim jezikom v 'jugoslovanskem' obdobju minimalne (srbohrvaščina), sedaj pa se povečujejo. Na drugi strani sta med Albanci uveljavljeni dve različici govorjene in pisane albanščine: na severu gegovska (razširjeno v severni Albaniji, uradno uveljavljeno na Kosovu) in na jugu toskovska (uradno velja v Albaniji). V vseh naštetih primerih ne preostane drugega kot zanesti se (z vso kritično distanco) na različne ocene, ki pa niso nujno slabše od uradnih statistik.

Večina preučevanih držav sodi že po lastnih statističnih navedbah med etnično relativno heterogene. To so države, kjer je delež glavne (nazivne, titularne) etnične skupnosti že pod 90 \%. Edino Albanija in Grčija odstopata od te podobe in se izkazujeta - vsaj statistično - kot etnično precej monolitni državi. V Grčiji uradno žive samo Grki in narodne pripadnosti popisi niti ne ugotavljajo, prav tako ne v Albaniji. Toda že primer Grčije je nazoren, saj nekateri viri navajajo za Grčijo vsaj 40.000 Makedoncev in ravno toliko Pomakov in Aromunov (Vlahov), medtem ko naj bi bilo Turkov do 60.000 (Pan in Pfeil 2000, 77-79). Zanimive so tudi ocene Albancev, saj jih uradne ocene poznajo le nekaj nad 20.000 (Pan in Pfeil 2000, 77), medtem ko naj bi jih bilo po drugih ugotovitvah veliko več, predvsem v severni regiji Epir (skoraj 200.000); podobno je tudi z Makedonci v grški Makedoniji (200.000) (Slovenski veliki leksikon, 2. knjiga, 2004, 521). Toda tudi nekateri grški viri govore o skoraj 300.000 prebivalcih grške kulture (torej Grki, sic!) v današnjem albanskem delu Epira (Meta 2006, 286-288). Nekatere ocene tudi Albanijo že uvrščajo med etnično heterogene, predvsem po zaslugi višjih ocen Vlahov in Romov; leta 2003 naj bi bilo prvih 139.000, Romov 109.000 in Grkov 66.000. Delež Albancev naj bi tedaj že padel pod 90 \%, kar razbija mit o etnično homogeni državi (Bërxholi 2005).

Posebne vrste problem je makedonsko vprašanje, kjer so se več kot stoletje dolgo odvijale kulturne in politične rivalitete srbskega, bolgarskega, grškega in v novejšem času čedalje bolj tudi albanskega nacionalizma. Zato se ocene števila pripadnikov posameznih skupnosti tudi v istem času zelo razlikujejo (Zupančič 2006a, 139-143). Prav to dilemo glede etnične pripadnosti si je izposodil britanski politični geograf J. Taylor, ko opisuje pojem 'balkanizacije' (Taylor 1989). Kot je bilo že omenjeno, Bolgari v svojih statistikah Makedoncev ne priznavajo kot samostojno narodno skupnost. Zaznal jih je en sam bolgarski popis po drugi svetovni vojni (1956), ko so bili odnosi med Bolgarijo in Jugoslavijo še dokaj dobri. Tedaj so jih našteli 188.000 (Eberhard 2003, 416). Deset let pozneje jih isti vir omenja 9600. Eberhard navaja za leto 1989, povzemajoč britanske ocene (Encyclopedia Britannica), številko 224.900, ki pa je narejena na podlagi ekstrapolacije in ocenjenih učinkov selitev in naravnega prirastka (Eberhard 2003, 472).

Uradna statistika tudi ne pozna Pomakov, sunitskih muslimanov bolgarskega jezika, temveč jih na podlagi jezikovnih kriterijev (enako velja tudi za Makedonce) šteje k večinskemu prebivalstvu (muslimanski Bolgari). Eberhard (2003, 419; citirano po Seewan in Dippold 1997, 1250) navaja v preglednici po okrajih skupno število 268.971 Pomakov. Najvišji delež (71 \%) dosegajo v okraju Smolin. Pan in Pfeil omenjata številko 200.000-280.000 (Pan in 
Pfeil 2000, 53), Kahl pa celo do 300.000 (Kahl 2006, 19). Vendar je pomaška zgodba bolj zapletena, saj naj bi po drugih virih ta skupnost zajemala od 170.000 do 260.000 pripadnikov, od tega 30.000 v grški Trakiji. Del Pomakov naj bi bil po izvoru slovanski (bolgarski?), drugi pa naj bi imeli predhodnike v Kumanih, ljudstvu turško-altajskega izvora, ki so bili najprej pokristjanjeni, v otomanski dobi pa so sprejeli islam. Isti vir domneva, da so (vsaj nekateri) lahko tudi potomci ljudstev, ki so jih naselili Turki pri kolonizaciji osvojenih ozemelj (Zimpel 1997, 427-428). Ker so jih nekateri šteli tudi k Turkom, je to v etničnih statistikah ustvarjalo kar nekaj zmede; povečevalo naj bi število Turkov. Po uradni statistiki naj bi jih bilo leta 1992 v Bolgariji 822.253 Turkov (Dimitrov 1995, 177), leta 2002 pa 746.664 (Census 2001 - final results), medtem ko Eberhard navaja, povzemajoč oceno Seewana in Dippolda, številko 847.584 (Eberhard 2003, 419). Pri tem ne pojasnjuje, ali je na to oceno že vplival eksodus okrog 300.000 Turkov v Turčijo v osemdesetih letih 20. st., ko so skušali bolgarske Turke nasilno bolgarizirati ali pa pregnati. Nekatere pokrajine, zlasti obmejna Strandža (ob meji s Turčijo) so skoraj povsem opustele (Karpat 1990, 7-19). Za leto 1992 navaja Eberhard na drugem mestu 800.000 Turkov, Makedoncev pa v teh statistikah ni (Eberhard 2003, 420). Nič manj težav ni pri ugotavljanju števila Romov, druge najštevilčnejše skupnosti v Bolgariji. Po uradnih podatkih naj bi jih bilo leta 2001370.908 (Census 2001 - final results) in nekaj manj po maternem jeziku (328.000), ocene pa se vzpnejo celo do 600.000 (Kahl 2006, 19; enako tudi Krasteva 1998). Ker Romi prakticirajo različne jezike in veroizpovedi, se v posameznih okoljih zaradi prilagajanja znajdejo tudi med drugimi etničnimi skupinami, kot so Turki, Vlahi in seveda med večinskim bolgarskim prebivalstvom.

Upoštevanje ocen in ne le uradnih statističnih podatkov spreminja tudi podobo Romunije, največje države Balkanskega polotoka. Medtem ko naj bi po podatkih zadnjega popisa delež Romunov znašal 89,5 \%, bi ob upoštevanju ocen, da sta številčnejši zlasti madžarska in romska manjšina, delež lahko nazadoval na vsega okrog 80 \%. Tako madžarski viri ocenjujejo število Sekeljev (transilvanskih Madžarov) na 2 mil. (Kocsis in Kocsis-Hodosi 1998, 25-26). Če k temu prištejemo še t.i. Čangose (madž. Csángó) v Moldaviji, ki jih Sasi ocenjuje na okrog 240.000 (Sasi 2002), se delež Madžarov poveča na več kot $10 \%$. Gre za skupino, ki je zaradi izolacije ohranila arhaično različico madžarščine z veliko romunskih primesi (moldavski dialekt) in uradne madžarščine praktično ne razumejo. Prav toliko ali pa še več pa naj bil bilo v Romuniji Romov: med 1,5 do 2,5 mil. (Fischer Weltalmanach 2009, 390). Uradne statistike so jih leta 1991 zabeležile 409.723 (Costachie 2000, 120).

Ob tem seveda ostaja še tretja, nekoč bistveno številčnejša skupina Nemcev (Sasov), ki je še leta 1930 štela 746.000 oseb (Eberhard 2003, 299). Po izvoru se delijo v dve skupini: Banatske Nemce, ki so to območje naselili v valu pozne agrarne kolonizacije južnega roba Panonske kotline v 18. st., ter bistveno starejšo skupino Sasov, ki so se naselili v visokem srednjem veku med 12. in 13. st., večidel kot rudarji in obrtniki. Zaradi odselitev po drugi svetovni vojni (pregon Nemcev) in nato še programirane vabljene selitve v poznih osemdesetih letih 20. st. v Nemčijo se je skupina močno zmanjšala. Nemška skupnost je bila tudi najbolj na udaru ob nasilnem preimenovanju toponimov, saj se je značaj saških naselij v južni Transilvaniji povsem spremenil. Mnoga naselja so tudi povsem zamenjali z novimi državnimi posestvi - starožitne saške vasi so zamenjali bloki sredi polj (Nicolae 2000, 1-6). Ob popisu leta 1991 so zabeležili še 119.436 Nemcev (Costachie 2000, 120), leta 2002 pa komaj še okrog 60.000 (Kahl 2006, 55-57). 
Zelo zanimiv primer je Črna gora. To po številu prebivalcev najmanjšo balkansko državo, ki ima stare zgodovinske korenine in s prvo Jugoslavijo prekinjeno državniško kontinuiteto, naseljujejo Črnogorci kot dominantna skupina. Toda njihov delež je med vsemi primerjanimi državami najskromnejši. Paradoks pa je, da je delež Črnogorcev najbolj nazadoval prav v fazi osamosvajanja države. Verjetno je k takemu učinku bolj kot realna sprememba identitete vplivala kalkulacija dela črnogorskega prebivalstva, da je v danih razmerah smiselna povezanost (zaradi gospodarskih in političnih razlogov) s Srbijo. Vendar je spričo večje demografske vitalnosti Bošnjakov (v Sandžaku) in Albancev na jugovzhodu pričakovati tudi naraščanje teh dveh skupin, tako da se lahko delež Črnogorcev še naprej zmanjšuje.

Podobno je pričakovati tudi v Makedoniji, čeprav so tam razmere bistveno bolj zapletene. Naglo povečanje deleža Albancev ni pripisati le visoki rodnosti znotraj te skupnosti, temveč tudi priselitvam v času po eksodusu s Kosova 1999. Mnogi begunci se niso vrnili, temveč so se naselili na robovih mest, zlasti Kumanova in Skopja. Kritični pretres zadnjih treh popisov, torej 1991, 1994 (popis 1991 je 1994 zaradi pritiskov doživel neke vrste ponovitev, ni pa pokazal večjih odstopanj) in 2002, kaže opazno povečanje deleža in absolutnega števila Albancev. Tako so v Kumanovu prvič presegli 50-odstotni delež (Madjevik 2006, 142-147). Mesto je v naslednjem desetletju še bolj spremenilo etnično podobo in postalo pretežno albansko (Zupančič 2006a, 146-147). Druga tendenca krepitve albanskega elementa v Makedoniji pa nastopa zaradi asimilacije nekaterih manjših skupin (npr. Goranov, Torbešev, pa tudi Turkov), ki je zaradi čvrstosti in še vedno močnega socializacijskega (v tem primeru torej asimilacijskega) vpliva družinskih vezi (asimilacija) praktično enosmerna (Trifunoski 1988).

Poleg tega je treba upoštevati še dve skupnosti, ki sta statistično 'manjši' zaradi razpršenosti in neorganiziranosti. Prvi so Vlahi oziroma Aromuni, ki jih regionalno, zlasti v južni Makedoniji, označujejo kot Cincarje. Po statistikah sicer ne dosegajo 10.000 oseb (Državen zavod za statistika Republike Makedonije), toda nekateri jih ocenjujejo na okrog 200.000 (Prevelakis 1996, 168). Isti avtor navaja tudi bistveno višjo oceno števila Romov; namesto statističnih okrog 54.000 naj bi jih bilo nad 200.000 (isti vir), po drugih navedbah pa celo okrog 260.000 (Klopčič in Polzer 1999). Vendar so take ocene verjetno pretirane (Madjevik 2006, 144).

V Srbiji je potem, ko je doživela erozijo državnega ozemlja zaradi osamosvojitve Črne gore in potem še Kosova, statistična slika pričala kazati (po desetletjih nasprotnih teženj) bolj srbsko podobo. Opazne spremembe so nastale v Vojvodini, in sicer zaradi selitev, ki so jih sprožile razmere v času Miloševićevega režima in vpetosti Srbije v vojaške konflikte na ozemljih nekdanje federacije. Zaradi strahu pred vpoklicem v vojsko in zaradi slabih gospodarskih razmer je Srbijo po ocenah zapustilo več kot deset tisoč ljudi. Toda po drugi strani sta bila zlasti Vojvodina in območje Beograda prizorišče doseljevanja beguncev; še leta 1996 jih je bilo več kot 600.000 (Kicošev 2006, 154-155). Zato se je delež Madžarov opazno znižal, na manj kot 300.000: leta 1991 je znašal še 344.000, leta 1961 pa še okrog 450.000 (Eberhard 2003, 387-388). Ob popisu leta 2002 so jih našteli 293.299 (Republika Srbija. Popis 2002). Delež Srbov se je povečal, vendar ne povsod. Zlasti na jugu sedaj potekajo podobni procesi kot na Kosovu. Število Albancev zaradi bistveno višje rodnosti večinoma narašča, niti radikalizirani odnosi zaradi kosovske krize jih niso bistveno omajali; po popisu 2002 jih je bilo 61.647, večinoma na jugu. Tudi v Srbiji so po ocenah Prevelakisa Romi in 
Vlahi številčnejši; prve ocenjuje na več kot 120.000, Vlahe pa na več kot 200.000 (Prevelakis 1996). Skoraj tolikšno število so dokazovali popisi leta 1953 (Kicošev, Kocsis in Jordan 2006, 61-63). Močno je nazadovalo tudi število Bolgarov (od 1953 še 56.000), leta 2002 pa še 20.497 (Statistical Office of the Republic of Serbia). Tega se ne da pojasniti zgolj z večdesetletno stalno tendenco demografskega praznjenja, temveč tudi s spremembami identitete.

Med države z izrazitimi težnjami etnične homogenizacije sodi Hrvaška. Zaradi eksodusa Srbov po operaciji Nevihta leta 1995 se je njihovo število več kot prepolovilo, spremenila so se tudi območja naselitve. V jugoslovanskem obdobju je bila to še številčna in vplivna skupnost: leta 1991 jih je bilo 581.000 oziroma nad $12 \%$, leta 1971 celo 626.789 ali skoraj $15 \%$ (Klemenčić 1993). Zaradi navedenih dogodkov je njihovo število do leta 2001 nazadovalo na vsega 202.000. Še bolj zanimiv je podatek, da je le četrtina (okrog 50.000) oseb pri zadnjem popisu navedla srbščino kot svoj materni jezik (Republika Hrvatska - Državni zavod za statistiku. Popis stanovništva 2001). Pri teh procesih ne gre prezreti bega Italijanov po drugi svetovni vojni; po oceni se jih je iz Istre in Dalmacije odselilo vsaj 130.000 (Magocsi 2002, 191-1993).

Prav tako je prišlo do izrazite regionalne etnične homogenizacije v Bosni in Hercegovini, čeprav so deleži ključnih treh skupnosti, bošnjaške, srbske in hrvaške, ostali približno v podobnih razmerjih kot pred jugoslovanskimi vojnami. V primeru Bosne in Hercegovine, deloma pa velja tudi za Srbijo, je treba omeniti fenomen 'Jugoslovanov'. V multietnični jugoslovanski federaciji je poskus, da bi se vzpostavil 'jugoslovanski' narod, naletel na različen, večinoma pa odklonilen odnos. Tudi ta poteza kaže, da so politične elite podcenile moč nacionalnih občutij in predvsem izjemne družbene dimenzije, ki se vzpostavlja prek narodne/ etnične pripadnosti. Toda v nekaterih okoljih je poskus naletel na sorazmerno ugoden odmev. Popis leta 1981 je pokazal skoraj 1,4 mil. pripadnikov (Veliki geografski atlas Jugoslavije 1987; tabele), ki pa se je povsem decimiral do naslednjega štetja leta 1991, ki so ga v nekaterih delih že pričakali skoraj z orožjem v rokah.

Trinarodna Bosna in Hercegovina je doživela izmed vseh območij nekdanje Jugoslavije najbolj radikalne spremembe, saj je morala domove zapustiti polovica prebivalstva (Pirjevec 2003). V letih od 1961 do 1991 se je delež Hrvatov znižal od dobre petine (21,7 \%) na 17,4 \%, še bolj pa delež Srbov, ki so od skoraj polovice (43 \%) nazadovali na manj kot tretjino (31,2 \%), delež Bošnjakov (ob popisu leta 1961 'Muslimani v etničnem smislu', leta 1971 'Muslimani v pomenu narodnosti'; Bošnjaki so 'postali' šele v devetdesetih letih) pa se je od četrtine (25,7 \%) povzpel na 43,5 \% (Federalni zavod za statistiku Federacije Bosne i Hercegovine). Vojno dogajanje in uveljavitev dvostopenjske federacije je uveljavilo povsem nova razmerja. Republika Srbska je ohranila večji del ozemlja (49 \%), na katerem sedaj živijo večidel le Srbi, bošnjaško-hrvaška federacija pa je uveljavila nekatere etnično dokaj homogene kantone, npr. Zahodnohercegovski (hrvaški), Unsko-sanski (bošnjaški) in nekatere mešane (npr. Hercegovsko-neretvanski). Sarajevo je kljub krvavim izkušnjam in številnim zameram v marsičem zadržalo svojo multietnično podobo, vse bolj pa jo dobiva tudi zvezni distrikt Brčko, a iz povsem drugačnih razlogov. Slednji postaja stekališče vseh izključno iz gospodarskih razlogov. 


\subsection{Dvodržavnost kot posebnost politično-teritorialne organiziranosti narodov na Balkanskem polotoku}

Predstavljene države so torej večinoma ostale razmeroma heterogene, kljub težnjam, da bi dosegli obratno. Upoštevaje nekatere ocene je torej le Grčija kolikor toliko homogena (nad 90 \% Grkov); vse ostale se torej soočajo s številčnimi manjšinami in večetničnimi situacijami. To je, kakor ugotavlja Seewan (1993), pri relativni mladosti držav očiten dodatni dejavnik varnostnih tveganj. Vendar pa bolj kot etnična heterogenost prebivalstva bode v oči neko drugo dejstvo, ki je povsem neprimerljivo z okoliščinami Srednje, Zahodne in Severne Evrope. Gre za pojav, da so narodi tudi politično-teritorialno organizirani v več državah. Po izkušnjah je namreč precej možnosti, da bodo politične elite - odvisno od priložnosti, ki jih nudijo širše mednarodne okoliščine - poskušale realizirati dva primarna cilja vseh nacionalizmov: združitev pripadnikov enega naroda $v$ okviru ene politično-teritorialne enote (države) in poskusi etnične homogenizacije znotraj državnih teritorijev. Oba pristopa sta s stališč sodobnih pogledov na državo in državljanstvo načeloma nesprejemljiva. Toda medtem ko je drugega mogoče pogosto slediti v različnih protimanjšinskih politikah marsikje tudi v stabilnih državah, so poskusi oblikovanja novih držav večinoma omejeni na krizna območja. Vsaj začasno se oblikujejo paradržave, ki jih potem prizna le majhno število držav ali pa sploh ne. Toda v teku mirovnih procesov so jih diplomati na nek način vendarle morali upoštevati. Predvsem pa de facto obstajajo in so torej realni del sodobnega političnega zemljevida. Podoben element so tudi različne etnične enklave, ki delujejo kot 'otoki'. Razmere v Bosni med leti 1992 in 1995 so bile značilen primer. Na Kosovu so se oblikovale srbske etnične enklave in večinoma obstajajo še danes. Take so bile 'krajine' na Hrvaškem, pa različni podobni pojavi na območju Kavkaza, v Palestini, Iraku, Afganistanu, Srednji Aziji, na Šrilanki, v Somaliji in marsikje drugod v Afriki.

Vse to so območja, ki so dobila svojo politično-teritorialno podobo v razmerah, ko so na temeljih večetničnih imperijev pomembno vlogo imele tuje sile. Nastale meje so torej kompromisna rešitev iz preteklosti. To dediščino pa morajo sedaj upravljati domače elite. Primeri Iraka in Afganistana, ki se po uspešni vojaški pacifikaciji soočajo z razdiralnimi silami etnično-teritorialne (in po drugi strani ideološke oziroma kulturne polarizacije) so lahko resen opomin, da so taka območja izredno ranljiva in torej skrivajo v sebi znaten konfliktni potencial. Toda po drugi strani je barviti etnični, verski in/ali kulturni mozaik bogastvo, ki se (večinoma) šele mora spremeniti v človeški kapital. Po drugi strani so se narodi znašli v pogojih dvodržavnosti. Slednji izraz sicer ni vedno ustrezen, saj ne gre v vseh primerih za de iure in de facto države, temveč za različne stopnje teritorialno-politične organiziranosti. Te okoliščine povečujejo obseg perifernih območij in ustvarjajo vrsto posebnosti v izgledu pokrajine, njeni strukturi in funkciji.

Hrvaška se je po razglasitvi neodvisnosti soočila z vstajo Srbov, ki so imeli v jugoslovanski vojski krepko podporo. Oblikovale so se t.i. srbske krajine. Potem ko so se izjalovili načrti oblikovanja 'Velike Srbije', so ta ozemlja de facto postala paradržave s specifičnim notranjim ustrojem in tesno naslonitvijo na Srbijo (tedaj še Zvezno republiko Jugoslavijo; Swift 2003, map 48). Poskusi mednarodnih misij, da bi zadržali nespremenljivost političnih meja in obenem dosegli kompromis, so se izjalovili. Po seriji uspešnih hrvaških protiofenziv, ki jih 
je zaključila že omenjena operacija Nevihta avgusta 1995, so bili srbski 'krajišniki' vojaško premagani (razen Vzhodne Slavonije, ki je prešla pod nadzor Hrvaške leta 1999). Krajine so kot element politično-teritorialne stvarnosti prenehale obstajati. Sledil je eksodus srbskega prebivalstva, zaradi katerega se je številčna, organizirana in vplivna srbska skupnost na Hrvaškem spremenila v nominalno precej zaščiteno, a dejansko šibko manjšino. Območje nekdanjih 'krajin' je ostalo redko naseljeno s pretežno ostarelim prebivalstvom in odločno nezadostno infrastrukturo. Revitalizacija je počasna tudi zaradi mnogih nerešenih vprašanj lastništva nepremičnin. Današnja pokrajinska podoba torej kaže vse značilne posledice vojne. Demografsko, gospodarsko in infrastrukturno opustela periferija je povsem odvisna od tuje pomoči (Rojs 2009). Toda opozoriti je treba še na številčno hrvaško prebivalstvo v Bosni in Hercegovini. Vsaj en kanton (Zahodnohercegovski) je naseljen pretežno s hrvaškim prebivalstvom. Kanton ima visoko stopnjo avtonomije v okviru hrvaško-bošnjaške federacije, ki jo sestavlja 10 kantonov, obstajajo torej politično-teritorialne enote $\mathrm{z}$ razmeroma visoko stopnjo avtonomije. Tako imajo zlasti na območju zahodne Hercegovine bosanski Hrvatje praktično svojo politično-teritorialno enoto.

Drugi narod z več političnimi enotami so Srbi. Poleg Srbije, znotraj katere ima poseben teritorialni status Vojvodina (v jugoslovanskem obdobju je bila avtonomna pokrajina), so Srbi nosilci oblasti v Republiki srbski (entiteta v Bosni in Hercegovini), nominalno pa tudi na Kosovu (kot konstitutivna skupnost). Prva je praktično notranja država, druga pa je teritorialno omejena na več malih, med seboj ločenih srbskih etničnih otokov. Življenje v enklavah ne omogoča polnega uživanja prednosti ne kosovskega in ne srbskega državljanstva. Njihovo delovanje v kosovskih organih in organizacijah oblasti je zelo omejeno, tudi zaradi agresivnega delovanja kosovsko-albanskih organizacij. Poleg tega nekateri vidijo 'Srbijo' tudi v Črni gori. Kot argument navajajo enak jezik in precej povezano ali celo skupno zgodovinsko usodo. Vrh vsega je tudi po uradnih podatkih delež Srbov zelo opazen in tudi srbski vpliv v Črni gori je sorazmerno velik.

Srbi se ob koncu 20. st. in v začetku tretjega tisočletja soočajo s krčenjem državnega ozemlja. Razpad Jugoslavije in oblikovanje 'krajin' je najprej povzročil drobljenje ozemlja, ki so ga Srbi opredeljevali kot 'svojega' (vključno z Jugoslavijo kot celoto). Po odpravi krajin na Hrvaškem in oblikovanju 'daytonske' Bosne in Hercegovine je breme vojne nekoliko prenehalo, toda oblikovane so bile nove meje. Republika srbska ima z oblikovanostjo ozemlja, posebej v vzhodnem delu kar nekaj težav, saj obsega gorato in kraško ozemlje, ki je prej imelo svoja regionalna središča zunaj tega območja. Z oblikovanjem meja in osamosvojitvijo Črne gore je vzhodna Hercegovina postala prometno težko dostopen žep. Sarajevo je razdeljeno, toda srbski del (Pale) je lahko le skromno središče. Poleg tega se utegne zgoditi nadaljnja regionalizacija Srbije (Vojvodina, tudi Sandžak).

Tuzla, prej pomembno regionalno središče, je sicer več kot podvojila število prebivalstva, a je v svojem mestoslužnem poslanstvu zelo omejena. Podobno je tudi z Dobojem in Zenico, ki sta z oblikovanjem novih notranjih meja pristali na robu in imata precej manjše gravitacijsko zaledje. Nasprotno pa doživlja distrikt Brčko, ki je neposredno pod zvezno vlado $\mathrm{BiH}$, nesluten razcvet zaradi posebnih olajšav, kar ustvarja posebne, očitno privlačne okoliščine. Na severnem robu Bosne so mesta (npr. Bosanska Kostajnica, Bosanski Novi, Bosanska Gradiška, Bosanski Brod), ki so se v zadnjem jugoslovanskem obdobju resno soočala 
z idejo po povezovanju in sodelovanju, sedaj ustvarila pregrajo. Take pregraje so se oblikovale tudi na Kosovu. Kosovska Mitrovica je razdeljeno mesto in nadaljevanje napetih odnosov med Srbi in Albanci bo skoraj zanesljivo okrnila njene razvojne možnosti. Srbske enklave živijo kot realno dokaj avtonomna ozemlja. Delujejo kot izogibališča in je malo verjetno, da bodo imele dovolj razvite servisne službe za lastno prebivalstvo. Odvisne bodo torej od sistematične in/ali priložnostne pomoči.

Albanci živijo sedaj v dveh državah, Albaniji in na Kosovu. Delež Albancev v obeh presega 90 \% prebivalstva. Poleg njiju je tudi zahodna Makedonija s pretežno albanskim življem de facto avtonomno ozemlje. Po ohridskem sporazumu (1993) imajo Albanci tudi zagotovljeno participacijo v državni upravi, kar dejansko (ne pa povsem dosledno tudi formalno) ustvarja avtonomnost njihovega poselitvenega ozemlja. V Črni gori imajo urejen status manjšine, v Grčiji, kjer naj bi jih bilo po nekaterih ocenah čedalje več, pa ne. Ta ozemlja so bila še pred nekaj leti skoraj izolirana med seboj. Z novimi načrti prometnih povezav od južnega Jadrana proti notranjosti se bo kohezivnost ozemelj z albanskim prebivalstvom gotovo povečevala.

Medtem ko smo Grčijo prej označili za etnično še najbolj homogeno (po grških navedbah naj bi bila povsem grška oziroma helenistična), lahko ugotovimo še eno dimenzijo. Gre za vprašanje Cipra, ki je po državljanski vojni v šestdesetih in sedemdesetih letih 20. st. ostal razdeljen na večji grški in manjši turški del. Grki predstavljajo večino (78 \%) prebivalstva (Benkovič Krašovec 2007, 40-45). Vmes ostaja 'nikogaršnje ozemlje', pas nenaseljenega sveta brez upravljanja. Dve britanski vojaški bazi (Dekélia in Akrotíri) sta prav tako ozemlji s posebnim statusom, formalno in funkcionalno izločeni iz državnosti 'Afroditinega' otoka. Vsi ti elementi povečujejo razdrobljenost Cipra, države, ki je formalno v celoti v EU, realno pa le grški del do 'Atilove' linije. Posebnost je tudi razdeljena prestolnica, podobno kot Sarajevo ali Jeruzalem. Sosednji državi imata torej na tem otoku drugo grško oziroma turško entiteto, ki sta si za nameček v bližnji preteklosti ostro konfrontirali tudi zaradi poteka morske meje (spor za pripadnost otočka Imia pred zahodno obalo Male Azije).

Makedonija zaradi svoje lege in velikosti težko konkurira večjim in močnejšim državam v sosedstvu. Vrh vsega ji Grčija odreka ime, Bolgarija pa samostojnost makedonskega naroda. S slednjo se po nacionalni mitologiji močno razlikujeta, čeprav imata obe državi npr. Cirila in Metoda ter 'carja' Samuela za svoji figuri, a z različnimi interpretacijami. Vrh vsega ima Bolgarija po idealizirani podobi ‘sanstefanskih' meja današnje makedonsko ozemlje za zgodovinsko 'bolgarsko'; k temu ozemeljskemu okviru naj bi spadali tudi t.i. 'šopski' kraji jugovzhodne Srbije (Stefanović in Krstić 1978). V luči bolgarskega razumevanja makedonskega vprašanja bi obstoječe stanje interpretirali kot obstoj dveh 'bolgarskih' držav.

Obstajata tudi dve romunski državi, Romunija in Moldavija. Z zgodovinskega vidika je Romunija primer sestavljene države: Vlaške, Moldavije in Transilvanije. Po osamosvajanju Vlaške v prvi polovici 19. st. se je ta razmeroma kmalu združila z Moldavijo, a le v zahodnem delu. Vzhodni del je prišel pod Rusijo (Besarabija), samostojno republiko pa so dobili po drugi svetovni vojni (Moldavska SSR). V času med obema svetovnima vojnama se je Romunija ozemeljsko skoraj potrojila in zajela celotno Besarabijo (ozemlje med Dnestrom in Prutom), etnično pa je iz dokaj homogene enote nastala izrazito heterogena država, kjer je bil delež romunskega prebivalstva le $72 \%$ (Eberhard 2003, 299). Vrh vsega sta se dve številčni skupini, Nemci in Madžari, ki sta bili prej (v okvirih habsburške monarhije) politično in gospodarsko 
dominantni, znašli v vlogi manjšin. Odnosi so bili zelo napeti. Med drugo svetovno vojno se je Madžarska razširila v Transilvanijo in Bukovino tako, da je zajela veliko večino ozemlja, naseljenega z madžarskimi Sekelji. Po drugi svetovni vojni se je morala Romunija odpovedati celotni Besarabiji, ki so jo v okviru rekonstrukcije Sovjetske zveze oblikovali v samostojno republiko Moldavijo. Realno ima torej današnje moldavsko državno ozemlje torej skupen zgodovinski izvor, vendar vsaj delno različno zgodovinsko usodo v moderni zgodovini (ki je čas oblikovanja narodov in nacionalnih držav).

Razpad socialističnega družbenega reda in pričetek osamosvajanja baltskih sovjetskih republik je tudi v Moldaviji budil upe ne le po boljšem življenju, temveč tudi po spremembi kulturne (etnične) orientacije. V zgodnjih devetdesetih letih je bila 'romunska' dimenzija notranje politike sorazmerno močna. Vendar so združevalno navdušenje zavrle in slednjič onemogočile po eni strani močne proruske sile, na drugi pa zadržanost Romunije zaradi slabega gospodarskega položaja v Moldaviji (King 2000, 164-167). Tako sta ostali državi ločeni. Med elemente ruskega pritiska sodi tudi spodbujanje in podpiranje pretežno z Ukrajinci in Rusi naseljenega ozemlja vzhodno od velikega akumulacijskega jezera na Dnepru. Ozemlje je postalo znano kot Pridnestrska republika, a sta njeno neodvisnost priznali le Rusija in Ukrajina. Težave in šibkost moldavskih oblasti je zaradi zelo slabega položaja izkoristila tudi razmeroma maloštevilčna, vendar kompaktno naseljena etnična skupnost Gagauzov, ki je prav tako razglasila neodvisnost in dobila nekaj ruske vojaške podpore, ne pa tudi političnega priznanja neodvisnosti (King 2000, 178-205). Po posredovanju OVSE in evropske diplomacije je bil z Gagauzijo dosežen sporazum, da se odpove neodvisnosti, ostane pa ozemlje z visoko stopnjo teritorialne avtonomije.

S tem pa se balkanska zgodba o oblikovanju specifičnih teritorijev nikakor ne konča. Gagauško izkušnjo ter osamosvajanje Kosova so kot svojo priložnost razumeli tudi v delu politične elite med romunskimi Madžari. Do tega sicer ni prišlo, a ostali so jeziček na tehtnici notranjepolitičnih odnosov v Romuniji.

\subsection{O funkcijah balkanskih ozemelj}

Funkcijska analiza ozemlja je razmeroma zamuden in zapleten postopek, kjer na podlagi objektivno ugotovljivih elementov v pokrajini ocenimo vlogo in pomen posameznih delov zemeljskega površja z določenega vidika. Začetniki in klasiki politične geografije so izhajali predvsem s stališča potreb lastne države. Prav to je v veliki meri botrovalo preimenovanju politične geografije v geopolitiko (Kjellen 1905; v Matznetter 1977, 78-98). Da je veda izgubila nekaj svoje akademske širine, so bili krivi nasledniki, ki so prezrli potrebo po kritični distanci in torej objektivizaciji subjektivne presoje vloge (funkcije) ozemlja. Seveda gre iskati razloge predvsem v filozofskem izhodišču klasične geopolitike, ki je tedaj pač temeljila na geografskem determinizmu ali na determinizmu nasploh. Po drugi svetovni vojni je geopolitika/politična geografija ${ }^{8}$ posegala po analizah ozemelj, upoštevajoč pri tem čedalje več t.i. družbenih elementov. Sodobne politične geografije niti ne govorijo izrecno o funkcijski analizi ozemelj ne v lokalnem ne v globalnem obsegu, vendar objektivno to počno.

8 Med izrazoma v anglosaksonskem svetu niti ne delajo posebne pomenske razlike, kar morda ustvarja nekaj zmede. 
Prav v ta kontekst sodi Cohenova regionalizacija (Parker 1997, 206-209) sveta na 'panregije', med katerimi lahko najdemo različne 'pasove' (npr. pas črepinj) oziroma 'mostišča'.

Postopek funkcijske analize torej poteka od proučitve strukturnih in morfoloških razmer k regionalizaciji (coniranju), kar nam da relativno homogena območja, ki pa jih je mogoče ocenjevati glede na realno in potencialno vlogo. Za razliko od drugih vidikov regionalizacije je političnogeografska izrazito dinamična. Istemu območju se lahko s spremembo razmer v okolici funkcija povsem spremeni. Noben tip površja, gospodarske usmerjenosti ali prebivalstvenih značilnosti torej ni avtomatično 'močno' ozemlje; moč mu bistveno določajo tako notranji (endogeni) kakor zunanji (eksogeni) elementi. Samo za primer: obalna ravnica $\mathrm{v}$ Albaniji je bila stoletja predvsem redko naseljena pregraja, v dobi bunkerjev je postala produkcijsko pomemben rob države, z morebitno namestitvijo npr. plinovodnega ali naftovodnega omrežja $z$ izhodiščem v Draču pa lahko postane sidrišče, jedro ali mostišče ipd.

Kakšne funkcije sploh lahko ima neko ozemlje? Razlikovati je mogoče pet skupin funkcij: bivalne, proizvodne, prometne, vojaško-strateške in simbolne. O bivalnih govorimo v smislu naselitvenega prostora neke skupnosti. Območja z gosto naselitvijo so pri tem praviloma favorizirana, saj poleg bivanja večjemu številu ljudi ustreza tudi koncentracija drugih funkcij. Prazna območja se praviloma štejejo za 'šibka'. Pri tem so pomembne tudi lastnosti prebivalstva (kot npr. starostna in spolna sestava, izobrazba, usposobljenost, znanje, tradicija itd., pa tudi npr. etnične poteze. Glavni indikatorji so število in lastnosti prebivalstva.

Nabor proizvodnih funkcij je zelo širok in zajema vse, od možnosti za kmetijsko pridelavo, prek rudnih in energetskih bogastev do proizvodnje v obliki industrije ali pa različnih storitvenih dejavnosti. Gre torej za izrazito ekonomske funkcije, ki so zgoščene na izbranem ozemlju. Indikatorjev je tukaj zelo veliko, od povsem kvantitativnih (finančni, količine določenih proizvedenih dobrin, zaloge dobrin) do kvalitativnih (znamka, ugled, ocena pomena ipd.).

Pri prometnih funkcijah govorimo predvsem o prepletu lege in tehnične infrastrukture, ki nekatera območja opredeljuje za koridorje in druge za pregrajo, oziroma za vozlišča ter prometno pasivna območja. Glavni indikatorji so torej potek, oziroma navzočnost infrastrukturnih objektov, gostota prometa (frekvenca) ter kakovostne opredelitve. Pri vojaškostrateških funkcijah so v ospredju bodisi s fizično izoblikovanostjo površja povezane lastnosti, ki naj bi bile npr. učinkovita pregraja za nasprotnika, ali pa (to sedaj veliko bolj) vojaška infrastruktura, ki močno poveča obrambno učinkovitost (na primer) nekega območja. Slednjič je tu še simbolni pomen, ki ga v največji meri izražajo npr. prestolnice, različni zgodovinsko pomembni kraji, romarska središča (sveta mesta) in sorodno. Pogosto gre zgolj za majhne, toda pomembne točke, ki jih neka skupnost še posebej izpostavlja kot pomembna.

Seveda na tem mestu ni priložnosti, da bi v vsej širini opredeljevali funkcije izbranih ozemelj, tako realnih kakor potencialnih. Omejili se bomo na najpomembnejše in najbolj izpostavljene.

Obravnavano območje Balkanskega polotoka je redkeje naseljeno kot mnogi predeli Južne, Srednje in Zahodne Evrope. Jedra gostejše poselitve so le v ožjem območju nekaterih prestolnic: Aten, Bukarešte, Beograda, Sofije in Zagreba, ostala jedra so manjša. Toda v zadnjem desetletju je zaradi velikih selitvenih premikov prišlo do oblikovanja gosteje naseljenih območij tudi na Kosovu in v osrednji Albaniji. Na drugi strani pa so obsežna peri- 
ferna območja, ki izstopajo po negativnih demografskih tendencah. Omenili smo jih v posebnem poglavju. Najbolj izstopajo predeli nekdanjih krajin na Hrvaškem, vzhodna Srbija, Rodopi in Strandža v Bolgariji, območja gorate Albanije in severni ter severovzhodni deli Romunije. Ob tem je treba podčrtati pretežno emigracijski značaj celotnega Balkana, razen že omenjenih središčnih območij, ki privlačijo predvsem prebivalce bližnjih območij. Celo več: ponekod je demografska erozija tolikšna, da potem postane dodatni dejavnik potiskanja prebivalstva drugam! Vendar je treba pomisliti tudi na možnost, da bodo demografsko izpraznjena območja $v$ primerih večjega priselitvenega pritiska v Evropo lahko postala cilj priseljencev.

Balkan je bil v preteklosti predvsem surovinska baza. V socialistični dobi je težnja po samozadostnosti oblikovala zaprta nacionalna gospodarstva, nekatera (albansko, romunsko) celo povsem zaprta. Po razpadu socialističnega sistema je sledil gospodarski šok in faza tranzicije, v kateri so se morale celotne panoge prilagoditi pogojem globalne konkurence. Ker je tranzicija potekala v soseščini medetničnih konfliktov in lokalnih vojn, je bila počasnejša in manj uspešna. V nekaterih državah je večina proizvodnih kapacitet prešla $\mathrm{V}$ tuje roke. Najbolj uspešna so bila nemška in avstrijska podjetja, ki so si uspela pridobiti ne le največjo gospodarsko izmenjavo, temveč obvladati tudi bančno-zavarovalniški sektor, naftne družbe, telekomunikacijske sisteme in tudi znaten del industrije. Zaradi nižje cene delovne sile, izogibanja strogim ekološkim normam in tudi osvajanja novih tržišč so nekatere države postale investicijsko dokaj privlačne. Tako se je v Romuniji po francoskih interesih revitalizirala strojna industrija, italijanska podjetja pa imajo tam domeno predvsem na področju tekstilne industrije. Italijanska podjetja posegajo zlasti v obalne predele Albanije s turističnimi kapacitetami in gradbeno industrijo.

Vstop Romunije in Bolgarije v EU je pospešil revitalizacijo nekaterih gospodarskih panog (npr. industrije, bančništva, zavarovalništva, trgovine), druge pa je skorajda zatrl. Tako se je morala makedonska tekstilna industrija in tudi pridelava bombaža umakniti poceni izdelkom iz Azije, zaradi zasičenosti kmetijskega trga pa je kvotni sistem vplival na močno zmanjšanje obsega kmetijske proizvodnje v Romuniji in Bolgariji. To je najbolj prizadelo predvsem periferna podeželska območja. Vojna je uničila glavnino industrijskih kapacitet $\mathrm{v}$ Bosni in Hercegovini, ki se sedaj težko obnavlja zaradi zapletene in drage administracije. Zato kljub boljšim izhodiščem leta 1990 (pred vojno) nima konkurenčnih prednosti pred državami z nizko ceno delovne sile (npr. Slovaško, Romunijo). Glede na prevlado uvoza nad izvozom v večini držav gre razvoj večinoma v smer povečevanja odvisnosti od drugih držav. Lahko ocenimo, da je Balkan bolj kot zaradi različnih oblik proizvodnje pomemben kot tržišče (zlasti za EU).

Toliko bolj izpostavljena pa je prometna in obenem strateška funkcija Balkana. Poglavitna prometnica poteka po savskem in moravskem koridorju in se pri Nišu razcepi v južni krak (proti Solunu in Atenam) ter proti Sofiji in Carigradu ter naprej v Malo Azijo. Pomen te smeri narašča $\mathrm{z}$ večanjem evropskih industrijskih podjetij v Turčiji (kar je dejansko tudi najpomembnejši motiv za vključitev Turčije v EU) in tudi turško tržišče. Poleg tega gre za območje, ki ima že več desetletij izrazito vlogo 'mostišča', ne le koridorja, povezujoč območje Kavkaza, Srednje Azije in Bližnjega vzhoda. Če je bil pomen turškega ozemlja v obdobju hladne vojne predvsem v vlogi bariere pred ruskim (sovjetskim) vplivom proti jugu, danes 
namesto tega stopata v ospredje predvsem njegova povezovalna vloga ter - kakor smo že omenili - Turčija kot proizvodna baza in tržišče. Strateški pomen turškega ozemlja je tudi v vojaškem smislu ostal zaradi procesov na območju Palestine in še bolj Iraka. Tega sta se dobro zavedali dve ključni sili, ki sta na prehodu iz drugega v tretje tisočletje skušali uveljavljati svoj vpliv na Balkanu: Rusija in ZDA (Vukadinović 2002). Toda tudi to je v veliki meri povezano z vidiki energetske oskrbe Evrope.

Plinska kriza pozimi 2009 je razkrila šibkosti evropske odvisnosti od energentov in spravila politike za geopolitično mizo. Pretehtati je treba, kako lahko EU zagotovi več med seboj neodvisnih in relativno stalnih virov energije. Potek plinovodov in naftovodov pa potrebuje fizično in družbeno neoviran, stabilen prostor, prek katerega te komunikacije potekajo (Grošelj 2009, 22-25). Balkan se s svojo umeščenostjo med črnomorski in levantski morski bazen ter maloazijsko kopnino ponuja kot dobra, če ne idealna rešitev.

Načrtovana sta dva ključna plinovoda, ki naj bi dovajala zadostne količine plina v Srednjo Evropo: Nabucco in Južni tok. Prvi je kopenski in poteka prek celotnega turškega ozemlja do Bolgarije in prek Romunije proti Srednji Evropi, drugi pa je pomorski in poteka od Novorosijska na črnomorski obali Rusije pod morjem do Bolgarije in potem v dveh krakih čez Grčijo do Jonskega morja, severni pa prek Srbije in Madžarske ter Slovenije v Italijo. Medtem ko naj bi prvi prevajal predvsem zemeljski plin iz južnokaspijskega bazena (Azerbajdžan, Turkmenistan), gre pri severnem predvsem za vire v Rusiji. A niso izključene še dodatne povezave, zlasti ne pri Nabuccu (možnosti priključitve zlasti Iraka in Irana, pa tudi Rusije; Kocsis in Tiner 2009, 52-59). Seveda pa s tem možnosti še niso izčrpane, saj je dobro pogledati tudi na možnosti transporta prek pristanišč, a to se v večji meri nanaša na transport nafte. V tem pogledu so zanimiva južnobalkanska pristanišča od Pireja in Soluna do Igoumenítse, Valone in Drača. S tem bi se pomorski pomen malih balkanskih držav lahko pomembno povečal, predvsem pa bi temeljito spremenil medregionalne povezave.

Natančno to težnjo je zaslediti v gradnji novih kopenskih povezav, ki jih žal udejanjajo le avtoceste. Te danes že povezujejo glavna središčna območja in prestolnice, povezanost z nekaterimi vozlišči (predvsem gre za dostop do pomembnih luk) pa še zaostaja. Medtem ko je avtocestna povezava od Reke do Madžarske že vzpostavljena, se jadranski obalni koridor pospešeno gradi. Prvi bo nesporno vplival tudi na konkurenco severnojadranskih pristanišč, drugi pa ima velik pomen zlasti za Hrvaško in njeno turistično gospodarstvo. Še večjo spremembo predstavljata gradnji dveh avtocestnih povezav od albanske obale pri Draču prek Tirane na Kosovo (severni krak) in prek Skopja na Sofijo. Nekoliko južneje poteka podobna prometnica prek severne Grčije od Igoumenítse na Solun. Te povezavo bodo nesporno favorizirale pomen Otrantskih vrat in albanske obale, pa tudi Tirane kot ključnega vozlišča. Dolgoročno to pomeni večjo povezanost t.i. albanskih ozemelj. Ameriške vojaška baza Bondsteel na Kosovu je postavljena ravno med obema prometnima krakoma, kar že samo po sebi pojasnjuje tudi vojaško strateški pomen ozemlja Kosova in Albanije, ki sta bila ves čas hladne vojne nepovezana otoka in so ju obšli skoraj vsi prometni in s tem tudi inovacijski tokovi.

Z vstopom Romunije in Bolgarije v zvezo NATO je nastal pomemben, morda odločilen korak v ozemeljski širitvi zavezništva. Na prvi pogled je ta korak videti sicer predvsem kot nadaljevanje starih, še globoko v čas hladne vojne (in še pred njo) segajočih načrtov 'ob- 
koljevanja Rusije'. Medtem ko za EU postaja Rusija vse bolj gospodarski partner, je na vojaško-strateškem področju drugače. Vstop omenjenih držav in leta 2009 še Hrvaške in Albanije v NATO je Rusijo povsem omejil. Tako zunaj zavezništva ostajajo le celinske države Srbija, Bosna in Hercegovina, Kosovo in Makedonija. Dve od teh sta pod nadzorom mednarodnih mirovnih sil. To območje Zahodnega Balkana torej sedaj deluje kot 'otok', ki ni vključen ne v EU in ne v NATO. Ker pa je v celoti obkrožen z državami članicami, je njegova perspektiva povsem v smeri pridruževanja evroatlantskim integracijam. Poleg že omenjenega vidika odnosov z Rusijo pa je širjenje zavezništva nedvomno tudi v vlogi varovalca miru na nekdanjih in potencialnih kriznih žariščih Balkanskega polotoka.

Nazadnje omenimo še pojem in pomen simbolne funkcije izbranih ozemelj. Ta še posebej izstopa pri nekaterih narodih. Tako imajo Srbi Kosovo polje povsem za svoje, toda to je danes na neodvisnem in pretežno albanskem Kosovu. Znana je grško-makedonska polemika glede regionalnih imen; rabo imena 'Makedonija' štejejo Grki za zlorabo in izražanje teritorialnih pretenzij. Makedonci in Bolgari imajo Ohrid za svojega (trdnjava in sedež Samuelovega carstva). Posebno mesto imajo pri tem prestolnice, tako nekatere zgodovinske kakor tudi sodobne (npr. Knin je ‘kraljevsko’ mesto Hrvaške, Veliko Tărnovo je bila nekoč prestolnica Bolgarije, Črna gora ima Cetinje ipd.). Simbolno pomembna območja so v zaostrenih medetničnih razmerjih zlahka predmet razdvajanja in tudi sporov.

\section{SKLEP}

Balkanski polotok izstopa po obsegu perifernih območij in razdrobljeni politično-teritorialni sestavi. Težnje po širjenju zlasti EU pogojujejo tudi reintegracijo teh ozemelj. Gre torej za koncept 'sestavljanja', ki mora z različnimi iniciativami ponovno vzpostaviti vezi, pretrgane z lokalnimi vojnami in spopadi. Stabilizacija politično-teritorialnih enot in zmanjševanje konfliktnega potenciala, ki ga izražajo prej opisana območja, je izrednega pomena tudi za opredelitev novih gospodarskih in prometno-strateških funkcij teh ozemelj. Perifernih območij in še posebej potencialnih konfliktnih žarišč se infrastruktura izogiba. Zato je deperiferizacija obsežnih območij Balkanskega polotoka ključnega pomena za njegov regionalni razvoj, pa tudi za bistveno večjo stopnjo uveljavljanja teh ozemelj, ne le kot ozkih koridorjev, temveč širših mostišč. Južni del 'vmesne Evrope', kot jo imenuje Tunjić (2004), je tako pred pomembnimi izzivi varnostnega, infrastrukturnega in gospodarskega predrugačenja. Je prostor, ki potrebuje reintegracijo.

$\mathrm{V}$ tem ne ravno enostavnem procesu se bo morala izkazovati evropska geopolitika. V ospredju sta dva vidika: regionalni in medkontinentalni. V okviru prvega je najbolj problematičen velik konfliktni potencial, ki ga generirajo zapleteni in neurejeni medetnični odnosi ter dopuščajo majhne in razmeroma šibke države. Te okoliščine ohranjajo periferni značaj obsežnih območij, slabijo gospodarske priložnosti in povečujejo število partnerjev, ki so potrebni za izpeljavo strateško pomembne infrastrukture. Toda v celoti smemo pričakovati povečevanje prometnega in strateškega pomena Balkanskega polotoka. Od sodelovanja med državami je odvisno, kolikšne bodo regionalne koristi posameznih politično-teritorialnih enot.

Pri medkontinentalnem vidiku je v ospredju predvsem vprašanje medcelinskih povezav, ki jih EU nesporno potrebuje za pokrivanje energetskih potreb. Poleg tega je v tem kontekstu 
odprto tudi vprašanje nadaljnje širitve EU in zveze NATO proti vzhodu. Širjenje bi nesporno spremenilo velikostna razmerja znotraj Evrope, Turčijo pa ponovno navezalo na evropsko kopnino, s katere je morala pred slabim stoletjem oditi. Na tem območju bi se ponovno pojavila kot ekonomsko, demografsko in vojaško močna regionalna sila, ki bi se neposredno navezovala na dve problematični krizni žarišči: Irak in Kavkaz. Obe območji pa izstopata tudi po svojem energetskem bogastvu. Balkan v tem pogledu povečuje svoj pomen, saj tudi sam, že zaradi svoje lege, predstavlja izvrstno strateško mostišče. Toda najprej potrebuje stabilno okolje.

V resnici bi torej EU potrebovala temeljito redefinicijo svojih 'vzhodnih politik', ki so bile do sedaj vse po vrsti parcialne in z veliko mero medsebojnega izigravanja. Balkan je bil le prizorišče, šahovsko polje, kjer so na moč figur bistveno vplivala razmerja v bližnji soseščini na eni ter zunanji dejavniki na drugi strani. Namesto celovite geopolitike se je uveljavljala lokalna kombinatorika. EU v celoti in skupaj bo morala pred izzivi regionalne pacifikacije, odpravljanja perifernosti in zagotavljanja strateških prednosti celotne Evrope temeljito spremeniti svoje pristope.

\section{Viri in literatura}

Atlas evropske zgodovine. Slovenska knjiga. Ljubljana 1996.

Atlas i Shqipërisë/Atlas of Albania/Atlas von Albanien. Tiranë 2003.

Banac, I. 1987: Nacionalno pitanje u Jugoslaviji. Porijeklo, povijest, politika. Globus. Zagreb. Banac, I. 2006: The politics of ethnic homogenity. V: War and change in the Balkans. Nationalism, conflict and cooperation, Cambridge University Press, str. 30-43. Cambridge.

Benkovič Krašovec, M. 2003: Bolgarija. Vodniki Ljubljanskega geografskega društva. Založba ZRC. Ljubljana.

Benkovič Krašovec M. 2007: Ciper. Vodniki Ljubljanskega geografskega društva. Založba ZRC. Ljubljana.

Bërxholi, A. 2005: Minoritetet në Shqipëri. Tiranë.

Biber, D. 1966: Nacizem in Nemci v Jugoslaviji 1933-1941. Cankarjeva založba. Ljubljana. Blgarite Atlas - The Bulgarian Atlas. Sofia 2001.

Brown, E. M. (ur.) 1993: Ethnic conflict and international security. Princeton University Press. Princeton.

Burg, S. L., Shoup, S. P. 2000: The war in Bosnia-Herzegovina. Ethnic conflict and international intervention. M. E. Sharpe. New York, London.

Calic, M.-J. 1996: Krieg und Frieden in Bosnien-Hercegovina. Suhrkamp Verlag. Frankfurt am Main.

Census 2001 - final results. National Statistical Institute of Republic of Bulgaria. Internet: http://www.nsi.bg/Census_e/Census_e.htm (10.9.2009)

Costachie, S. 2000: Ethnic minorities in post-communist Romania. V: Post-communist Romania: Geographical perspectives. Liverpool Hope Press, str. 119-124 Liverpool.

Dimitrov, R. 1995: Sicherheitspolitik und ethnische Konflikte aus bulgarischen Sicht. Minderheiten als Konfliktpotential in Ostmittel- und Südosteuropa. R. Oldenburg Verlag. München. 
Dokumente të prodhuara 2003-2006. Ministrae Mjedisit dhe Planifikimit Hapësinor, Instituti për Planifikim Hapësinor. Prishtinë 2003 (CD; arhiv avtorja).

Državen zavod za statistika Republike Makedonije. Internet: http://www.stat.gov.mk (10.9. 2009)

Eberhard, P. 2003: Ethnic groups and population changes in twentieth-century CentralEastern Europe. History, data and analysis. M. E. Sharpe. New York, London.

Enciklopedija Jugoslavije, 3. knjiga. Leksikografski zavod FNRJ. Zagreb 1958.

Erdeli, G. 2000: Geo-demographic trends in rural Romania. V: Post-Communist Romania: Geographical perspectives. Liverpool Hope Press, str. 67-74. Liverpool.

Federalni zavod za statistiku Federacije Bosne i Hercegovine. Internet: http://www.fzs.ba/ Dem/Popis/Nacionalnost\%20opcine\%20Popis\%201991.pdf (Stanovništvo prema izjašnjenju o nacionalnoj pripadnosti po opštinama 1991) (10.9.2009)

Fischer Weltalmanach 1999. Fischer Verlag. Frankfurt am Main 1998.

Fischer Weltalmanach 2009. Fischer Taschenbuch Verlag. Frankfurt am Main 2008.

General Secretariat of the National Statistical Service of the Greece. Internet: http://www. statistics.gr/portal/page/portal/ESYE (10.9.2009)

Gerolymatos A. 2002: The Balkan wars. Conquest, revolution, and retribution from the Ottoman era to the twentieth century and beyond. Basic Books. New York.

Glassner, M. I. 1993: Political geography. John Wiley \& Sons. New York.

Grošelj, K. 2009: Energetske igre brez meja. Revija Obramba 41, 9, str. 22-25. Ljubljana.

Hobsbawm, E. J. 2004: Nationen und Nationalismus. Mythos und Realität seit 1780. Campus Verlag. Frankfurt am Main.

Hofbauer, H. 2001: Balkankrieg. Zehn Jahre Zerstörung Jugoslawiens. Promedia. Wien.

Hofbauer, H. 2008: Experiment Kosovo. Die Rückkehr des Kolonialismus. Promedia Verlag. Wien.

Hupchick, D. P., Cox, H. E. 2001: The Palgrave historical atlas of the Balkans. Palgrave. New York.

Ilies, A. 2004: Romania. Euroregiuni. Editura Universității din Oradea. Oradea.

Janko, S. 1983: Weg und Ende der Deutschen Volksgruppe in Jugoslawien. Leopold Stocker Verlag. Graz.

Johnston, R. J. 1982: Geography and State. Macmillan. London.

Kahl, T. 2006: Ethnisches Bewusstsein in Mittel und Südosteuropa um 2000. V: Atlas Ostund Südosteuropa, Map 2.9, Begleittext. Wien.

Karpat, K. H. 1990: The Turks of Bulgaria. The History, culture and political fate of a minority. The Isis Press. Istanbul.

Kennedy, P. 2002: Aufstieg und Fall der großen Mächte. Ökonomischer Wandel und militärischer Konflikt von 1500-2000. Fischer Taschenbuch Verlag. Frankfurt am Main.

Kicošev, S. 2006: Human resources of Serbia and Montenegro. V: Structural analysis of spatial and human resources for interregional cooperation in southeast Europe, Slovenia and Austria. Oddelek za geografijo, str. 152-160. Ljubljana.

Kicošev, S., Kocsis, K., Jordan, P. 2006: Serbien (Srbija), Montenegro (Crna gora). V: Atlas Ost- und Südosteuropa, 2.9. Ethnisches Bewusstsein in Mittel- und Südosteuropa. Österreichisches Ost- und Südosteuropa-Institut, Begleittext, str. 60-65. Wien. 
King, C. 2000: The Moldovans. Romania, Russia and the politics of culture. Hoover Institution Press. Stanford.

Kjellen, R. 1905: Geopolitische Betrachtungen über Skandinavien. Ponovno objavljeno v Matznetter, J. (ur.), 1977: Politische Geographie, str. 77-98. Wissenschaftliche Buchgesellschaft. Darmstadt.

Klemenčić, M. 1993: A concise atlas of Croatia and the Republic of Bosnia and Hercegovina. Leksikografski zavod Miroslav Krleža. Zagreb.

Klemenčič, M., Zupančič, J. 2004: The effects of the dissolution of Yugoslavia on the minority rights of Hungarian and Italian minorities in the Post-Yugoslav states. Nationalities papers 32, 4, str. 853-896. London.

Klemenčič, M., Žagar, M. 2004: The former Yugoslavia's diverse peoples. ABC CLIO. Santa Barbara.

Klopčič, V., Polzer, M. (ur.) 1999: Wege zur Verbesserung der Lage der Roma in Mittel- und Osteuropa. Beiträge aus Österreich und Slowenien. Ethnos 54. Wien.

Kocsis, K., Kocsis-Hodosi, E. 1998: Ethnic geography of the Hungarian minorities in the Carpathian basin. Geographical Research Institute RCES. Budapest.

Kocsis, K., Tiner, T. 2009: Geopolitics of pipelines and Eastern Europe with special regard to Hungary. Hungarian Geographical Bulletin 58, 1, str. 46-67. Budapest.

Kostopoulou, S. 1996: Thessaloniki and Balkan realities. Reconstructing the Balkans. John Wiley \& Sons. New York.

Krasteva, A. (ur.). 1998: Communities and identities in Bulgaria. Longo Editore. Ravenna.

Krastev, I. 2004: Weak states as a security threat. Südosteuropa Mitteilungen 44, 4, str. 102 115. Special Issue (Five Years of Stability pact). Südosteuropa Gesellschaft. München.

Lovenjak, D. 2006: Etnične razmere v zahodni Makedoniji. Diplomsko delo, Oddelek za geografijo, Filozofska fakulteta Univerze v Ljubljani. Ljubljana.

Madjevik, M. 2006: Human resources in Macedonia. V: Structural analysis of spatial and human sources for interregional cooperation in Southeast Europe, Slovenia and Austria, str. 142-147. Ljubljana.

Magocsi, P. R. 2002: Historical atlas of Central Europe. University of Washington Press. Seattle.

Matznetter, J. (ur.) 1977. Politische Geographie. Wissenschaftliche Buchgesellschaft. Darmstadt.

Mazower, M. 2002: Temna celina: dvajseto stoletje. Mladinska knjiga. Ljubljana.

Meta, B. 2006: Greek-Albanian tension 1939-1949. Academy of Sciences of Albania, Institute of History. Tirana.

Natek, K., Natek, M. 2006: Države sveta. Mladinska knjiga. Ljubljana.

Nejašmić, I. 2006: Spatial characteristics of demographic development ofCroatia. V: Structural analysis of spatial and human sources for interregional cooperation in Southeast Europe, Slovenia and Austria, str. 147-151. Ljubljana.

Nicolae, I. 2000: Changes of Romanian place names during the communist era. V: PostComunist Romania: Geographical perspectives. Liverpool Hope Press, str. 1-6. Liverpool. 
Nurković, R. 2006: Human resources in Bosnia and Herzegovina. V: Structural analysis of spatial and human sources for interregional cooperation in Southeast Europe, Slovenia and Austria, str. 134-141. Ljubljana.

Nurković, S., Mirić, R. 2006: The political-territorial system of Bosnia and Herzegovina as a factor of transformation of the regional-geographical structure. V: The western Balkans, str. 421-436. Koper.

Pan, C., Pfeil, B. S. 2000: Die Volksgruppen in Europa. Ein Handbuch. Wilhelm Braumüller Verlag. Wien.

Parker, G. 1997: Geopolitika v 20. stoletju. Fakulteta za družbene vede. Ljubljana.

Pirjevec, J. 2003: Jugoslovanske vojne 1991-2001. Cankarjeva založba. Ljubljana.

Prevelakis. G. 1996: Les Balkans. Cultures et géopolitiques. Nathan. Paris.

Ratzel, F. 1896: Die Gesetze des räumlichen Wachstums der Staaten. Ein Beitrag zur wissenschaftlichen politischen Geographie. Petermans Mitteilungen 42, str. 97-107). Ponovno objavljeno v Matznetter, J. (ur.) 1977: Politische Geographie. Wissenschaftliche Buchgesellschaft. Darmstadt.

Republika Hrvatska - Državni zavod za statistiku. Internet: http://www.dzs.hr/hrv/censuses/census2001/Popis/Hdefault.html (tabela 12: Stanovništvo prema narodnosti, po gradovima/opčinama) (10.9.2009)

Republika Srbija. Popis 2002. Stanovništvo, domaćinstva i stanovi. Podaci prema opštinama, knjiga 10, Beograd 2004.

Rizopoulos, Y. 2003: Foreign direct investment and Western firms internationalization strategies in the Balkan countries. V: The development of the Balkan region, str. 75-112. Burlington.

Rogelj, B. 2006: Nazaj k Evropi - Geopolitični diskurzi o Srednji in Vzhodni Evropi v institucijah Evropske unije. Dela 26, str. 181-202. Ljubljana.

Rojs, S. 2009: Revitalizacija kriznega območja na primeru Kninske krajine. Diplomsko delo, Oddelek za geografijo, Filozofska fakulteta Univerze v Ljubljani. Ljubljana.

Sasi, A. 2002: Csángóföld Pamântul Ceangâilor. Budapest.

Seewan, G. (ur.) 1993: Minderheiten als Konfliktpotential in Ostmittel- und Südosteuropa. R. Oldenbourg Verlag, Südosteuropa-Gesellschaft. München.

Seewan, G., Dippold, P. 1997: Bibliographisches Handbuch der ethnischen Gruppen Südosteuropas. Südosteuropa Gesellschaft. München.

Seton-Watson, H. 1977: Nacije i države. Ispitivanje porijekla nacija i politike nacionalizma. Globus. Zagreb.

Slovenski veliki leksikon. Mladinska knjiga. Ljubljana 2003-2005.

Smith, D. 2003: The Atlas of war and peace. Earthscan Publications Ltd. London.

Statistical Office of the Republic of Serbia. Internet: http://webrzs.statserb.sr.gov.yu/axd/en/ index.php (10.9.2009)

Statistical Yearbook 2007. Institutul National de Statistica. Internet: http://www.insse.ro/ cms/rw/pages/anuarstatistic2007.en.do (10.9.2009)

Stefanović, M., Krstić, M. 1978: Apostolski Mihajlo: Velikobugarske pretenzije od San Stefana do danas. Vuk Karadžić. Beograd. 
Swift, J. 2003: The Palgrave concise historical atlas of the cold war. Palgrave Macmillan Ltd. Hampshire.

Tanner, M. 1997: Croatia. A Nation forged in war. Yale University Press. New Haven.

Taylor. A. J. P. 1956: Habsburška monarhija 1815-1918. Državna založba Slovenije. Ljubljana.

Taylor, P. J. 1989: Political geography. World-economy, nation-state and locality. Longman Science and Technical. London.

Toal, G., Dahlman, C. 2006: Has ethnic cleansing succeded? Geographies of minority return and its meaning in Bosnia and Herzegovina. V: The western Balkans, str. 349-366. Koper.

Totev, S. 2001: The Bulgarian economy in transition: Possibilities for cooperation with Balkan countries. V: The development of the Balkan region, str. 317-358. Burlington.

Trifunoski, J. 1988: Albansko stanovništvo u Socialističkoj Republici Makedoniji. Književne novine. Beograd.

Tunjić, F. 2004: Vmesna Evropa. Znanstvenoraziskovalno središče Koper. Koper.

Tunjić, F. 2006: The 'Europe in Between' and the OSCE. V: The western Balkans, str. 151178. Koper.

Veliki geografski atlas Jugoslavije. Sveučilišna naklada Liber. Zagreb 1987.

Vöckler, K. 2008: Prishtina is Everywhere. Turbo-Urbanismus als Resultat einer Krise. Parthas Verlag. Leipzig.

Vukadinović, R. 2002: Varnost v Jugovzhodni Evropi. Fakulteta za družbene vede. Ljubljana.

Zavod za statistiku Republike Crne gore. Internet: http://www.monstat.org (10.9.2009)

Zgodovina narodov Jugoslavije, 2. knjiga. Državna založba Slovenije. Ljubljana.

Zimpel, H.-G. (ur.). 1997: Lexikon der Weltbevölkerung. Nikol Verlag. Hamburg.

Zupančič, J. 2006a: Geopolitične razsežnosti makedonskega narodnega vprašanja. Razprave in gradivo 48-49, str. 124-154. Ljubljana.

Zupančič, J. 2006b: Geografski pristopi k proučevanju kriznih območij. Dela 26, str. 161-179. Ljubljana.

Zupančič, J. 2008: Albansko vprašanje v luči političnoteritorialne rekonstrukcije Balkana. Razprave in gradivo 55, str. 6-49. Ljubljana.

\section{POLITICAL-GEOGRAPHICAL ANALYSIS OF THE BALKANS}

\section{Summary}

The paper deals with contemporary dimensions of political map of the Balkans. After a brief introduction and some methodological remarks, the main content is dedicated to morphological, structural and functional analysis of nation-states and other formal politicalterritorial phenomena in the large area between Danube River and five seas: Adriatic, Ionian, Aegean, Sea of Marmara and Black Sea.

Balkans alias Southeastern Europe is a region of peripheries and a mosaic of cultural and political structures. Old historical paths, used for more than 4000 years, put this area 
to core region in historical sense. However, through the whole modern era the Balkans was a periphery, a 'Europe-in-between' or truly a 'shatter belt'. This situation followed the disintegration of two multinational empires, Ottoman and Austrian (or Austro-Hungarian). In the large area along their frontiers, new small nation-states have been created: Greece, Bulgaria, Romania, Serbia and Montenegro. After the erosion of Turkish rule in two 'Balkan' wars in 1912 and 1913, those countries became stronger, larger and more heterogeneous. Some observers called this process of territorial-political fragmentation as 'balkanization'. With the continuation of this process after World War I, the political map changed radically again. The main two new forces were multicultural Yugoslavia (at the beginning the State of Serbs, Croats and Slovenes) under Serbian rule, and Romania, a country, constructed from three different parts and traditions. After World War II, the political entities remain their places in general, but the borders changed. With the exception of Greece, all countries put the communist elites to the power. Four decades later, in 1990 and beyond, the communist regimes have been erased. Yugoslavia collapsed on 'ethnic-suture'. This new episode of balkanization brought into being seven new countries instead of former Yugoslav federation. Probably, this process of fragmentation is still not finished. However, at the moment, this picturesque mosaic of small countries reflects the common characteristics of the whole Balkan peninsula. There are only two countries (Greece and Romania) counted as middlesized states; all others have less than 100.000 sq. km and 10 million of inhabitants.

The peripheral areas are very extensive. Small countries - large border-areas - large peripheries. Beside this, there are still some additional reasons for concern. Because of local wars and bloody interethnic conflicts in Croatia, Bosnia and Herzegovina and Kosovo, some areas became totally marginalized. A strong decrease of population who fled to main regional centres, create a specific crisis area, emptied of inhabitants, with destroyed infrastructure and collapsed economy. The cultural landscape has been destroyed and changed, too. On the other hand, a strong flow of refugees came to regional centres. This is so-called 'crisis urbanization', presented in some Bosnian and Kosovar cities. Priština, for example, increased from 210.000 inhabitants to around half a million! Some cities are now divided: Sarajevo, Mostar and Kosovska Mitrovica are good cases. Some montainous areas in Macedonia (state), or in Bulgaria and Romania, are far from modernization. Eastern Serbia is emptying, as well as southeastern Thrace (Bulgaria) or Eastern Carpathians. The large peripheries are a 'weak belly' of these countries.

Despite all nationalisms, exploded after the fall of communist rule, targeted to homogenization of their states and territories, most of researched countries are ethnically heterogeneous. Large minorities on one hand and phenomenon of double-states (or other forms of political-territorial units) reflect well the typical 'Balkan story'. The Croats are organized beside Croatia, of course, in a 'Croat' canton in western Herzegovina. Serbs live in Serbia, Bosnia (second largest ethnic group living in a para-state or special entity Republika Srpska). According to the constitution, the Serbs in Kosovo are one of constituent ethnicities. Romanians are organized in two countries: Romania and Moldova, Greeks in Greece and Cyprus (mainly in southern part of the island). So, instead of strong, homogeneous states, we have a number of weak regions and countries and large peripheral regions. Peripherization 
is a threat, and trap: a serious obstacle on the way to more successful economy and social conditions.

The last part of the paper is dedicated to different functions of Balkan space and territory. This part of Europe is less populated than other regions of old continent (besides Scandinavia). The above mentioned peripheries are economically weak and demographically emptied. They represent some kind of demographical 'depressions'. Despite this, Balkans is still a reservoir of working-force. The migration trends to Central and Western European countries are significant. Also, the production and economical characteristics are not the best advantage. The Balkans is important as a market and for new investments. The transportation, transit and strategic role ob Balkan peninsula is increasing, particularly after the interethnic conflicts and local wars. There are several important traffic corridors passing through this territories: from Central Europe through the Sava and Morava River corridor and then divide into two directions: through Sofia and Istanbul to Turkey and farther to the east, and from Niš to Saloniki and Athens to the south. The second traffic corridor follows eastern Adriatic coast. Then, there are two completely new directions: from Priština to Tirana and Drač (Durrës) on Albanian coast, and from Durrës to Skopje and Sofia. Both directions are very important for stronger spatial cohesion between territories, settled by Albanians. Beside this traffic corridors, in last few years two main projects occupied the geopolitical arena: gas pipelines Nabucco and Southern Stream. The first one is an European consortium (Turkey, Bulgaria, Romania, Hungary, Austria, Germany), the second one is more or less RussianItalian combination. 


\section{Slika 1: Centralna in periferna območja Balkana}

Figure 1: Central and peripheral areas of the Balkans

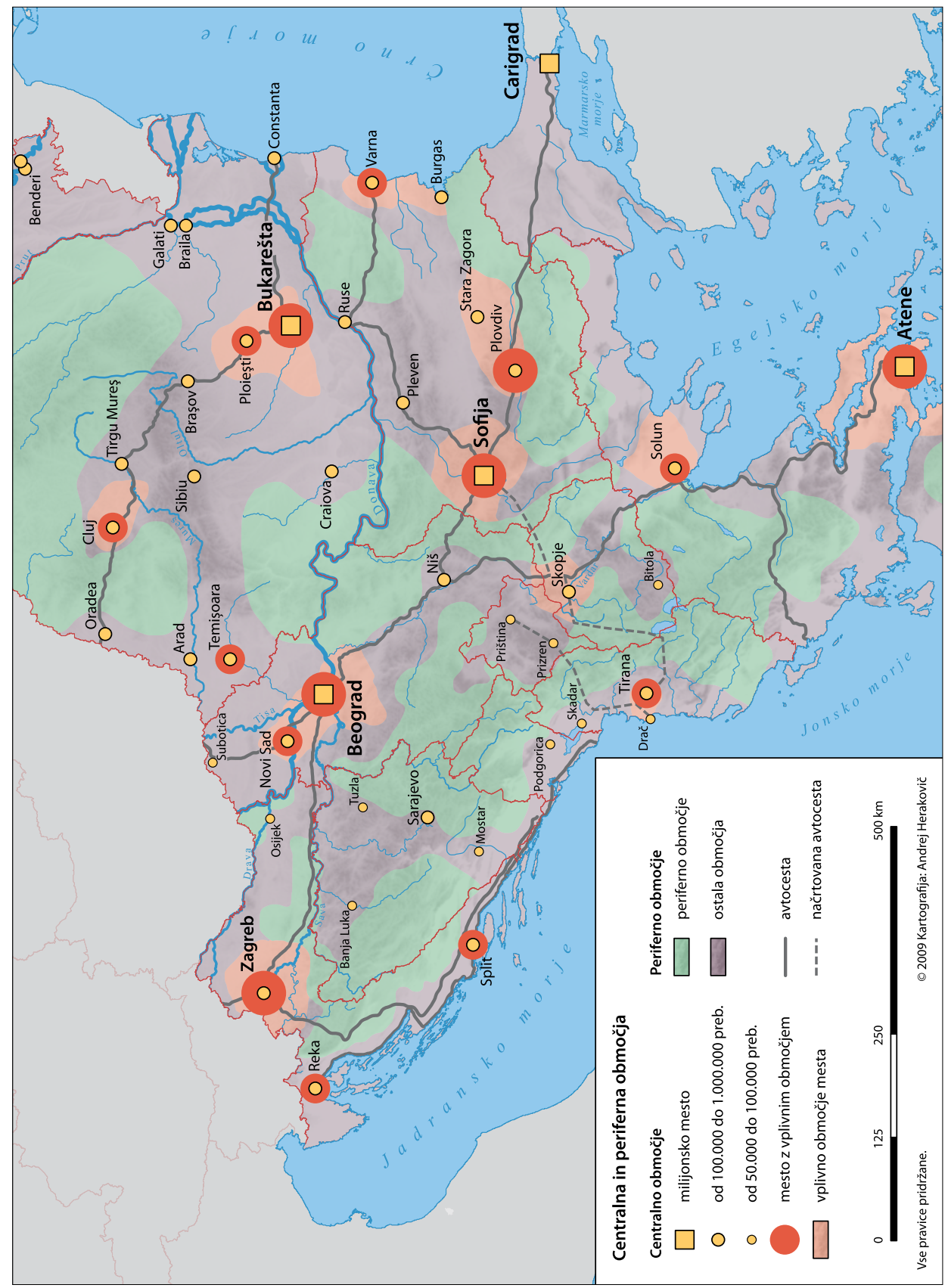


Slika 2: Politične meje, začasne politične tvorbe in manjšine na Balkanu

Figure 2: Political borders, temporary political units and minorities in the Balkans

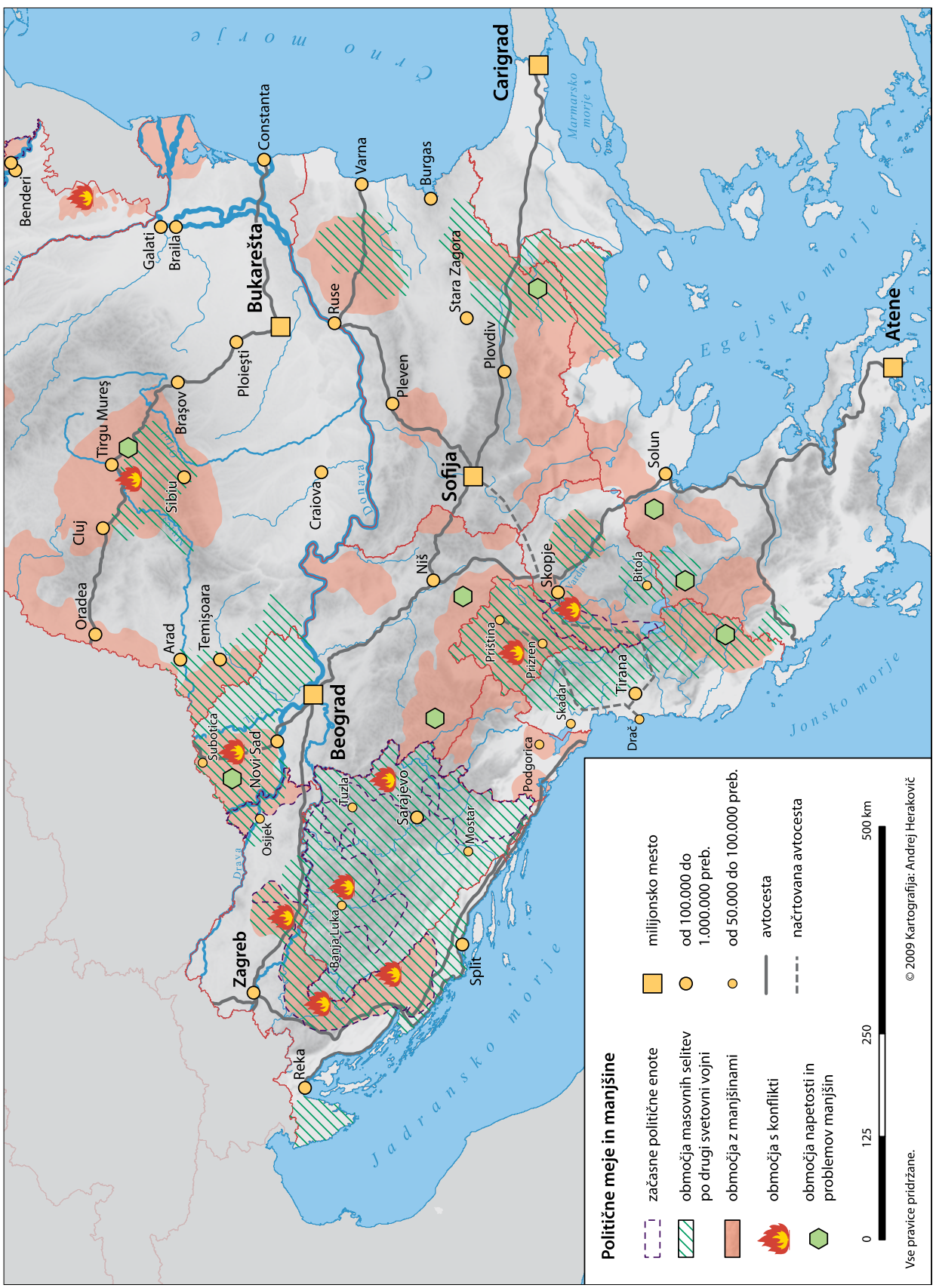


Slika 3: Tranzicijski in transportni pomen Balkana

Figure 3: Transit and transport function of the Balkans

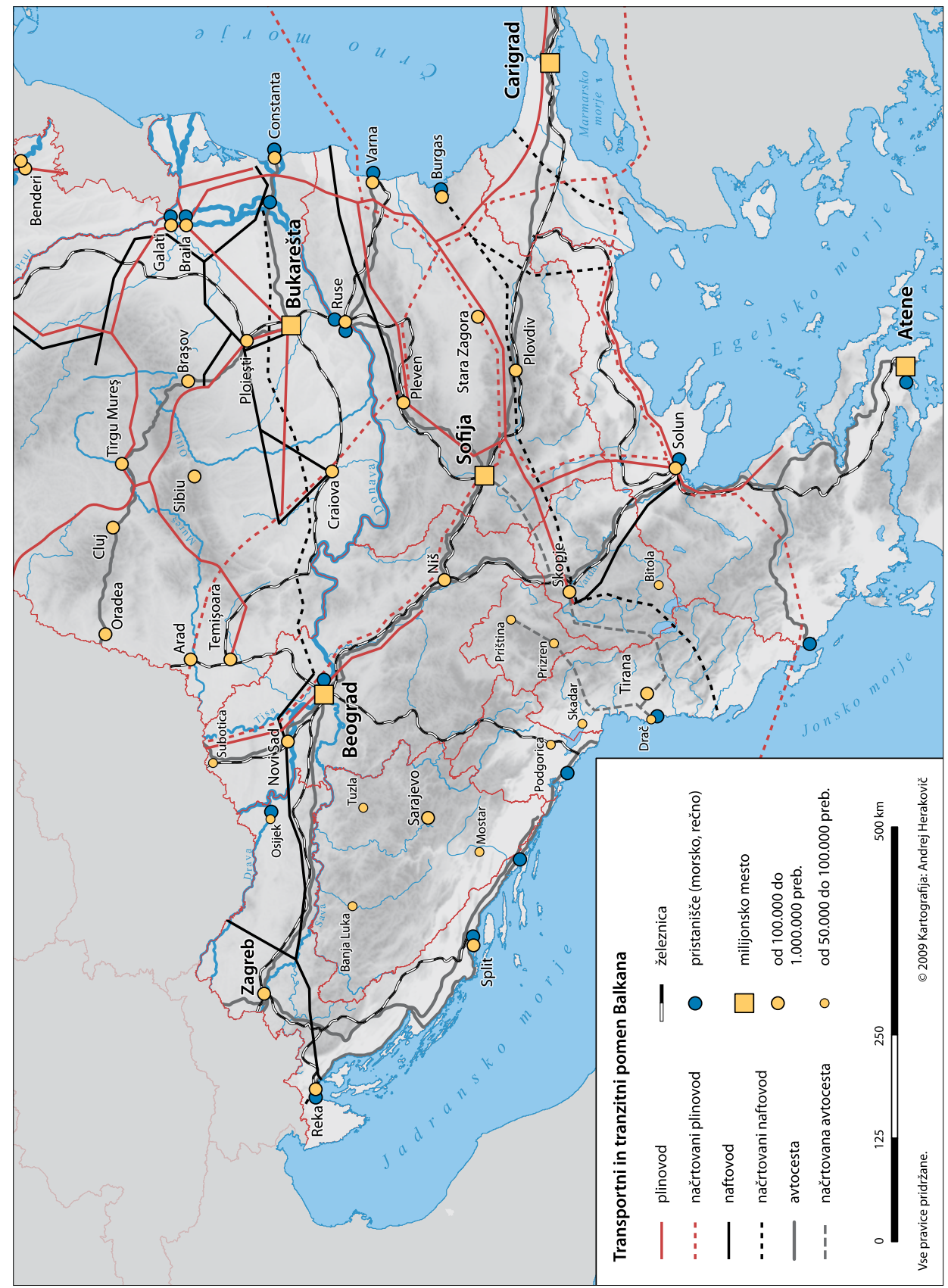

